УДК 553.2:553.434

\title{
ПАРАГЕНЕЗИСЫ МИНЕРАЛОВ И ФОРМЫ ИХ ВЫДЕЛЕНИЯ - КАК ОТРАЖЕНИЕ ЭТАПОВ ФОРМИРОВАНИЯ МЕСТОРОЖДЕНИЙ МЕДИСТЫХ ПЕСЧАНИКОВ И СЛАНЦЕВ
}

\author{
Трубачев Алексей Иванович', \\ jesika-m@yandex.ru
}

\author{
Корольков Алексей Тихонович ${ }^{2}$ \\ baley51@mail.ru
}

\author{
Радомская Татьяна Александровна', \\ taniaojigova@mail.ru
Забайкальский государственный университет,
2 Иркутский государственный университет, Россия 664003, г. Иркутск, ул. Карла Маркса, 1.
${ }^{3}$ Институт геохимии им. А.П. Виноградова СО РАН, Россия, 664033, г. Иркутск, ул. Фаворского, 1 А \\ Россия, 672039, г. Чита, ул. Александро-Заводская, 30.
}

Актуальность. Генетические представления о генезисе месторождений медистых песчаников и сланцев активно обсуждаются в специальной литературе. Несмотря на различные подходы в этой дискуссии, исследование парагенезисов главных рудных минералов разновозрастных месторождений медистых песчаников и сланцев остается критерием достоверности выдвигаемых гипотез.

Цель: на основе большого фактического материала по взаимоотношениям главных рудных минералов выделить этапы образования месторождений медистых песчаников и сланцев.

Объекты: месторождения и рудопроявления медистых песчаников и сланцев Кодаро-Удоканской зоны и сравнительный анализ полученных результатов по другим 74 меденосным зонам.

Методы: проведение геологоразведочных работ с изучением закономерностей размещения, условий образования, особенностей строения, вещественного состава месторождений и рудопроявлений медистых песчаников и сланцев; минераграфические исследования парагенезисов главных рудных минералов.

Результаты. В рудах месторождений медистых песчаников и сланцев установлены многочисленные минералы, которые, срастаясь между собой, образуют парагенетические ассоциации, разделенные по степени распространения на главные, второстепенные и редкие, а по условиям формирования - на седиментационно-диагенетические, постдиагенетические и гипергенные. Между минералами отмечаются самые разнообразные структурные взаимоотношения (пластинчатые, решетчатые, взаимопроникающих границ, субграфические, замещения, зернистые, коррозионные, порфиробластические и др.). Наиболее характерны формы выделения отдельных минералов и их парагенезисов: вкрапленная, пятнистая, слоистая (параллельная, ритмично-пачечная, волнистая, косая), конкреционно-глобулярная, прожилковая, каемчатая, линзовидная, гнездовая, просечковая, колломорфная, порошковато-землистая, натечная и др., которые в целом отражают основные этапы формирования пород и руд месторождений медистых песчаников и сланцев: седиментогенез-диагенез-катагенез-метаморфизм-гипергенез. Формирование минералов, их парагенезисов и форм выделения определяется при седиментогенезе: величиной рН, карбонатностью среды, литолого-фациальной обстановкой, климатом; при диагенезе: величинами Eh и pH среды рудообразования, растворимостью сульфидов, концентрацией металлов, сульфат-ионов и $\mathrm{H}_{2} \mathrm{~S}$; при катагенезе и метаморфизме: повышенными температурами и давлениями, действием метаморфогенных и постмагматических растворов; при гипергенезе: реакциями окисления и восстановления, электрохимическими и бактериальными процессами, зависимыми от гипсометрии, тектоники, литологических особенностей, климата, минерального состава первичных руд.

\section{Ключевые слова:}

Месторождения медистых песчаников и сланцев, парагенезис минералов, структура, текстура, формы выделения, этапы, условия формирования.

\section{Парагенезисы минералов, их структурные} взаимоотношения и формы выделения

Под парагенетической ассоциацией понимается естественная совокупность минералов, характеризующаяся определенным составом, структурнотекстурными взаимоотношениями слагающих индивидов и агрегатов, обусловленными определенной последовательностью возникновения минералов и закономерностями распространения [1]. В этом определении учитываются структурно-текстурные взаимоотношения минералов, их состав, распределение в пространстве, последовательность появления во времени.

Анализ материала по 74 меденосным зонам и провинциям месторождений медистых песчаников и сланцев (ММПС) позволил выделить парагенезисы по степени распространения: главные, второстепенные и редкие; по условиям формирования: седиментационно-диагенетические, постдиагенетические и гипергенные (таблица).

Главные парагенезисы представлены взаимоотношениями основных рудообразующих минера- 
лов. При минераграфическом исследовании в рудах медистых песчаников и сланцев Удоканского месторождения выявлен халькозин двух модификаций: 1) $\beta$-халькозин, или собственно халькозин моноклинной сингонии, обнаруженный в парагенезисе с борнитом и имееющий гипогенное происхождение; 2) $\alpha$-халькозин, или дигенит, - тригональная низкотемпературная модификация, которая формируется в результате распада неустойчивой гексагональной высокотемпературной модификации халькозина и имеет гипергенный генезис. Минералы халькозиновой группы весьма тесно связаны с борнитом (рис. $1,2-e$ ). Выделяются два главных типа срастания этих минералов: взаимопроникающих структур и субграфических, свидетельствующих об их близко одновременном формировании, иногда с признаками замещения борнита халькозином. В группе халькозина постоянно отмечаются тесные срастания собственно халькозина, джарлеита и дигенита (рис. $1, a-8)$. Структурные взаимоотношения этих минералов вполне определенные: пластинчатые, решетчатые, пятнистые, свидетельствующие об их близко одновременном образовании [2].

К важнейшему парагенезису медистых песчаников и сланцев относится борнит-халькопиритовый (рис. $1, \varkappa_{-u}$ ). В их взаимоотношениях намечаются срастания типа взаимопроникающих структур, иногда с признаками замещения халькопирита борнитом или, наоборот, борнита халькопиритом. В большинстве же случаев трудно сказать, какой из этих минералов образовался раньше, а какой позднее.

Довольно широко развит парагенезис халькопирит-пирит (рис. $1, \kappa-м$ ). В малоизмененных рудах признаки коррозии пирита халькопиритом проявлены слабо, тогда как в метаморфизованных разностях это явление выражено довольно отчетливо. Нередко в этих же метаморфизованных рудах можно наблюдать появление порфиробластовых кристаллов пирита на фоне сплошных или вкрапленных выделений халькопирита или пирротина (рис. $1, л, л)$.

Некоторые исследователи [3] считают, что только срастания соседних сульфидов: борнит-халькозин, борнит-халькопирит, халькопирит-пирит, стоящих в зональных рядах близко, являются парагенетическими и термодинамическими устойчивыми и равновесными. Отсюда делается, на наш взгляд, неверный вывод о том, что сульфиды, стоящие в разных частях зонального ряда, не являются парагенезисами, т. к. они осаждались неодновременно из разных по происхождению растворов или вследствие резких изменений условий рудогенеза. Этому выводу противоречат факты почти одновременного образования главных минералов и так называемые промежуточные парагенезисы: халькозин-борнит-халькопирит и борнит-халькопирит-пирит, структурные срастания которых, как и соседних парных минералов борнит-халькозин, халькопирит-борнит и др., свидетельствуют об их синхронности.
A.М. Лурье считает эти срастания разновременными и неустойчивыми - вначале образовался пирит, а потом через какое-то время из вновь поступающих меденосных растворов шло осаждение медных сульфидов [3]. Однако наблюдения показывают, что часто (особенно в конкрециях) пирит и халькозин чередуются попеременно друг с другом, или, наоборот, пирит окаймляет халькозин либо борнит. Этому явлению можно дать другое объяснение. Сульфиды меди осаждались чуть раньше пирита, а иногда и близко одновременно. Хорошо известно [4], что термодинамика этого процесса определяется количеством органики. Когда ее мало, то, действительно, в первую очередь осаждаются сульфиды меди, а на осаждение пирита ее уже не хватает. Поэтому-то и не видим совместно сросшихся сульфидов меди и железа в рудах медистых песчаников. Другое дело - медистые сланцы, в которых содержание органики в несколько раз выше, чем в песчаниках, поэтому ее количества хватает на формирование и медистых сульфидов, и пирита, совместное нахождение которых мы и наблюдаем во многих районах.

Парагенезис галенита и сфалерита, иногда теннантита и других минералов с медными сульфидами в большинстве случаев относится к второстепенным, хотя в некоторых месторождениях (Джезказган, Мансфельд, Польша и др.) его вполне можно считать главным. Во взаимоотношениях галенита и сфалерита с медными сульфидами чаще всего отмечаются взаимопроникающие структуры, когда нельзя с твердой уверенностью определить более ранний и поздний минерал. Следует отметить, что галенит ассоциирует чаще с борнитом, хотя отмечены его срастания также с халькозином, халькопиритом и теннантитом, в то время как сфалерит срастается больше с халькопиритом и, естественно, с галенитом, а также с теннантитом, пиритом, очень редко с халькозином. Из этого можно заключить, что термодинамические условия роста сфалерита более благоприятны в халькопиритовой и пиритовой зонах.

В рудах меденосных формаций встречается довольно большое число редких минералов, которые тесно ассоциируют с основными медными сульфидами. Виттихенит установлен в рудах Кодаро-Удоканской, Предсудетской, Западнопредальпийской зон, ряде проявлений Северо- и Южноафриканской провинций. Срастается он чаще всего с борнитом и халькозином, нередко в кварц-кальцитовых прожилках образует более крупные гнезда и просечки. В зоне окисления по трещинкам в нем развиваются прожилки бисмутосферита (бисмутит). Из других висмутовых минералов с медными сульфидами ассоциируют иногда самородный висмут (Джезказган, Красное, Мангышлак), висмутин (Африканские проявления), которые, так же как и виттихенит тяготеют к борнитовой зоне.

Молибденит в качестве редкого минерала встречается довольно часто, находится в парагенетических связях с борнитом и халькопиритом, а 
Таблица. Состав, формы выделения и этапы форлирования парагенезисов минералов меденосных зон и провинций ММПС [2-69]

Table. $\quad$ Composition, forms of recognition the stages of formation of parageneses of minerals in copper-bearing zones and CSSD provinces [2-69]

\begin{tabular}{|c|c|c|}
\hline \begin{tabular}{|c|} 
Седиментационно-диагенетические парагенезисы \\
Sedimentation-diagenetic parageneses
\end{tabular} & $\begin{array}{c}\text { Постдиагенетические парагенезисы } \\
\text { Postdiagenetic parageneses }\end{array}$ & $\begin{array}{c}\text { Гипергенные парагенезисы } \\
\text { Hypergenic parageneses }\end{array}$ \\
\hline \multicolumn{3}{|c|}{ Донецкая зона (нижняя пермь)/Donetsk zone (lower Perm) } \\
\hline $\begin{array}{l}\text { 1. Cc- Bn } \\
\text { 2. Bn-Chp } \\
\text { 3. Chp - Py } \\
\text { 4. Cc- Py - Mrc } \\
\text { 5. Chp- Bn - FO- Gn - Cc } \\
\text { 6. Gn - Sph - Py - Mrc } \\
\text { 7. Cin }-\mathrm{Gn}-\mathrm{Py}-\mathrm{Sph}\end{array}$ & $\begin{array}{l}\text { 1. Bn - Cc } \\
\text { 2. Bn-Chp } \\
\text { 3. Py - Chp - Bn - Cc } \\
\text { 4. Chp - Py - Cal }\end{array}$ & $\begin{array}{l}\text { 1. } \mathrm{Cv}-\mathrm{Mal}-\mathrm{Az} \\
\text { 2. Tnr }-\mathrm{Cup}-\mathrm{Mal}-\mathrm{FeH}-\mathrm{Chrs} \\
\text { 3. Cer }-\mathrm{Smth}-\mathrm{FeH}-\mathrm{Mal}-\mathrm{Az}\end{array}$ \\
\hline $\begin{array}{l}\text { Вкрапленная, конкреционная, псевдоморфозы } \\
\text { по растительным и животным остаткам, глобу- } \\
\text { ли, оолиты, послойные образования } \\
\text { Disseminated, concretionary, pseudomorphs on } \\
\text { plant and animal fossils, globules, oolites, layered } \\
\text { formations }\end{array}$ & $\begin{array}{l}\text { Прожилки, гнездово-линзовидная, явление за- } \\
\text { мещения } \\
\text { Streaks, nest- and lens-shaped, replacement }\end{array}$ & $\begin{array}{l}\text { Корочки, плёнки, почки, каёмки, прожилки, } \\
\text { псевдоморфозы } \\
\text { Crusts, films, buds, rims, streaks, pseudo- } \\
\text { morphs }\end{array}$ \\
\hline \multicolumn{3}{|c|}{ Юг Сибирской платформы (кембрий)/South of Siberian platform (Cambrian) } \\
\hline $\begin{array}{l}\text { 1. Cc-Bn (Py) } \\
\text { 2. Bn - Chp - Tnt }- \text { Gn (Sph) } \\
\text { 3. Chp - Py - Bn - Asp (Mol) } \\
\text { 4. Cc-Bn- } \mathrm{Au}(\mathrm{Ag})\end{array}$ & $\begin{array}{l}\text { 1. Chp }-\mathrm{Bn}-\mathrm{Hm} \\
\text { 2. Chp }-\mathrm{Bn}-\mathrm{Gn}-\mathrm{Cal} \\
\text { 3. Chp - Py - Cal }\end{array}$ & $\begin{array}{l}\text { 1. } \mathrm{Cc}-\mathrm{Cv}-\mathrm{Mal}-\mathrm{Az} \\
\text { 2. Cup }-\mathrm{Tn} r-\mathrm{Cu}-\mathrm{Lm} \\
\text { 3. Chp }-\mathrm{Bn}-\mathrm{Cc}-\mathrm{Cv}\end{array}$ \\
\hline $\begin{array}{l}\text { Вкрапленная, слоистая, конкреции, оолиты, } \\
\text { глобули, псевдоморфозы } \\
\text { Disseminated, layer, concretions, oolites, globu- } \\
\text { les, pseudomorphs }\end{array}$ & $\begin{array}{l}\text { Прожилки, гнёзда, сгустки, просечки } \\
\text { Streaks, nests, clots, flasers }\end{array}$ & $\begin{array}{l}\text { Каёмки, натёки, корочки, пластинчато-решёт- } \\
\text { чатые, сферолиты, землистые массы } \\
\text { Rims, incrustations, crusts, lamellar-lattice, } \\
\text { spherulites, earthy accumulations }\end{array}$ \\
\hline \multicolumn{3}{|c|}{ Юг Сибирской платформы (венд) / South of Siberian Platform (Vendian) } \\
\hline $\begin{array}{l}\text { 1. Bn - Cc (Dg, Dj, Anl, Au - Ag) } \\
\text { 2. Bn - Chp (Car) } \\
\text { 3. Chp - Tnt - Py - Sph } \\
\text { 4. Chp - Py - Flt - Bar (Bn) } \\
\end{array}$ & $\begin{array}{l}\text { 1. Bn-Cc }(\mathrm{Dj})-\mathrm{Cal}(\mathrm{Qz}) \\
\text { 2. Bn - Cc - Gn } \\
\text { 3. Bn-Chp - Hm - Qz (Cal) } \\
\text { 4. } \mathrm{Hm}-\mathrm{Mgt}\end{array}$ & $\begin{array}{l}\text { 1. Синий/blue } \mathrm{Cv}-\mathrm{Anl}-\mathrm{BnA} \\
\text { 2. Cc- Cv }-\mathrm{Dg}-\mathrm{Mal}-\mathrm{Az}-\mathrm{Lm} \\
\text { 3. Chp }-\mathrm{Bn}-\mathrm{Cv}\end{array}$ \\
\hline $\begin{array}{l}\text { Вкрапленная, слоистая, глобули, конкреции } \\
\text { Disseminated, layer, globules, concretions }\end{array}$ & $\begin{array}{l}\text { Прожилки, гнёзда, линзочки, просечки } \\
\text { Streaks, nests, lenses, flasers }\end{array}$ & $\begin{array}{l}\text { Каёмки, прожилки, налёты, корочки, земли- } \\
\text { стые массы, пластинчато-решётчатые формы } \\
\text { Rims, streaks, incrustations, crusts, earthy ac- } \\
\text { cumulations, lamellar-lattice forms }\end{array}$ \\
\hline \multicolumn{3}{|c|}{ Кодаро-Удоканская зона/Kodar-Udokan area } \\
\hline $\begin{array}{l}\text { 1. Bn - Cc - Dg (Ag, Au, Mol, Car) } \\
\text { 2. Bn - Chp - Tnt (Car, Mol) } \\
\text { 3. Chp - Tnt - Gn - Sph - Py (Asp, Mol, Mrc) } \\
\text { 4. Chp - Py - Po (Mlr, Asp) } \\
\text { 5. Mgt - Hm - Zrn - Apt (MC) }\end{array}$ & 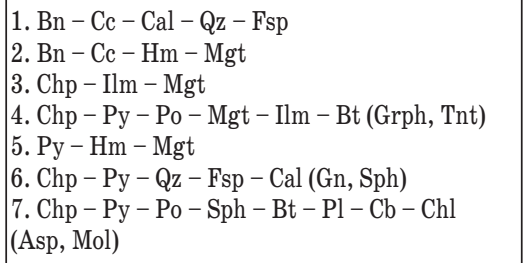 & $\begin{array}{l}\text { 1. Cc- Cv - Bn - Mal - Az - Tnr }-\mathrm{Cu}-\mathrm{Chrs}- \\
\text { Cup - Lm } \\
\text { 2. Brch - Chlc-Antl - Gy - Jr - Cv - Cc - Lm } \\
\text { 3. Промпродукты/Industrial Products: } \\
\text { Mrc- Ру - Mlk - Lm }\end{array}$ \\
\hline $\begin{array}{l}\text { Вкрапленная, слоистая, каёмчатая, } \\
\text { конкреции (?) } \\
\text { Disseminated, layer, rims, concretions (?) }\end{array}$ & \begin{tabular}{|l|} 
Просечки, прожилки, сланцеватые формы, \\
гнёзда, линзы, крупные агрегаты, метакри- \\
сталлы, порфиробласты, конкреции (?) \\
Flasers, streaks, shale forms, nests, lenses, large \\
aggregates, metacrystals, porphyroblasts, conc- \\
retions
\end{tabular} & $\begin{array}{l}\text { Прожилки, каёмки, сферолиты, псевдоморфо- } \\
\text { зы, землистые массы, натёки, корки, пластин- } \\
\text { чато-решётчатые формы } \\
\text { Streaks, rims, spherulites, pseudomorphs, } \\
\text { earthy accumulations, incrustations, crusts, la- } \\
\text { mellar-lattice forms }\end{array}$ \\
\hline \multicolumn{3}{|c|}{ Джезказганское месторождение (карбон)/Dzhezkazgan deposit (Carbon) } \\
\hline 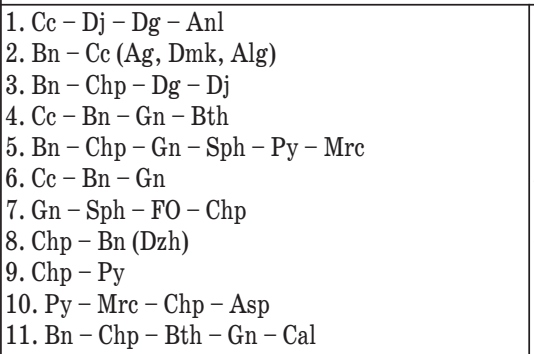 & 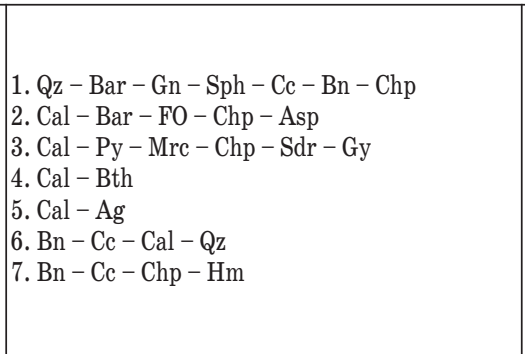 & $\begin{array}{l}\text { 1. Cc }-\mathrm{Cv}-\mathrm{Brch}-\mathrm{Cu}-\mathrm{Cup}-\mathrm{Mal}-\mathrm{Az}-\mathrm{Lmp} \\
\text { 2. Nntk - Atk - Antf - Btl - Psmal - Chrs - } \\
\text { Mal - Az - Lm } \\
\text { 3. Hll - Med - Chrs - Opl - Chlcd - оксиды Mn/ } \\
\text { Mn oxides - Mal - Az - Psmal } \\
\text { 4. Bv - Atk - Lnr - Mal - Cer - Antl - Ntr }\end{array}$ \\
\hline $\begin{array}{l}\text { Слоистая, вкрапленная, конкреции, рулетопо- } \\
\text { добные и оползневые формы, кластические дай- } \\
\text { ки (вкрапленность) } \\
\text { Layer, disseminated, concretions, roll-like and } \\
\text { landslide forms, clastic dikes (impregnation) }\end{array}$ & $\begin{array}{l}\text { Прожилки, просечки, гнёзда, линзы, зальбан- } \\
\text { ды трещин, секреции, брекчии } \\
\text { Streaks, flasers, nests, lenses, salband cracks, } \\
\text { secretions, breccia }\end{array}$ & $\begin{array}{l}\text { Каёмки, прожилки, натёки, корочки, колло- } \\
\text { морфные, зернистые агрегаты, секреции, кри- } \\
\text { сталлы } \\
\text { Rims, streaks, incrustations, crusts, colloform, } \\
\text { granular aggregates, secretions, crystals }\end{array}$ \\
\hline
\end{tabular}




\section{Окончание таблицы}

Table

\begin{tabular}{|c|c|c|}
\hline $\begin{array}{c}\text { Седиментационно-диагенетические парагенезисы } \\
\text { Sedimentation-diagenetic parageneses }\end{array}$ & $\begin{array}{l}\text { Постдиагенетические парагенезисы } \\
\text { Postdiagenetic parageneses }\end{array}$ & $\begin{array}{l}\text { Гипергенные парагенезисы } \\
\text { Hypergenic parageneses }\end{array}$ \\
\hline \multicolumn{3}{|c|}{ Айнакское месторождение (венд)/Aynak deposit (Vend) } \\
\hline $\begin{array}{l}\text { 1. Bn - Chp (Mol) } \\
\text { 2. Chp - Py (Cob, Sml, Grsd, Ann, Saf) } \\
\text { 3. Py - Chp - Po, Grph (Glc, Pn, Mlr) } \\
\text { 4. Sph, Chp, Py - Mrc }\end{array}$ & $\begin{array}{l}\text { 1. Po- Chp - Bn } \\
\text { 2. } \mathrm{Mgt}-\mathrm{Ilm}-\mathrm{Chp}-\mathrm{Bn} \\
\text { 3. } \mathrm{Qz}-\mathrm{Hm} \\
\text { 4. Qz-Dol- Chp - Fsp }\end{array}$ & $\begin{array}{l}\text { 1. } \mathrm{Cc}-\mathrm{Cv}-\mathrm{Dg}-\mathrm{Cu}-\mathrm{Mal}-\mathrm{Az}-\mathrm{Cup}-\mathrm{Lm} \\
\text { 2. Brch - Chlc-Chrs } \\
\text { 3. } \mathrm{Ery}-\mathrm{Khv}-\mathrm{Lmp}-\mathrm{Psm}-\mathrm{Lm}\end{array}$ \\
\hline $\begin{array}{l}\text { Слоистая, вкрапленная } \\
\text { Layer, disseminated }\end{array}$ & $\begin{array}{l}\text { Гнёзда, линзы, просечки, крупные агрегаты, } \\
\text { прожилки, сланцеватые формы } \\
\text { Nests, lenses, flasers, large aggregates, streaks, } \\
\text { shale forms }\end{array}$ & $\begin{array}{l}\text { Прожилки, каёмки и псевдоморфозы, земли- } \\
\text { стые массы } \\
\text { Streaks, rims and pseudomorphs, earthy accu- } \\
\text { mulations }\end{array}$ \\
\hline \multicolumn{3}{|c|}{ Гарц-Тюрингенская зона (пермь верхняя)/Harz-Thuringian zone (upper Perm) } \\
\hline $\begin{array}{l}\text { 1. Bn - Cc - Dg (Ag, Strm) } \\
\text { 2. Bn - Chp - Py - Mrc - Gn - Sph (Dg, Cv) } \\
\text { 3. Chp - Py - Tnt - Ln - Mlr - Eng } \\
\text { 4. Gn - Sph - Chp - Py - Mrc (Po, Asp }) \\
\text { 5. Cv - Id - Py - Chp }\end{array}$ & $\begin{array}{l}\text { 1. } \mathrm{Cc}-\mathrm{Bn}-\mathrm{Hm}-\mathrm{Gn}-\mathrm{Sph} \\
\text { 2. } \mathrm{Bn}-\mathrm{Chp}-\mathrm{Cal} \\
\text { 3. } \mathrm{Gn}-\mathrm{Sph}-\mathrm{Py}-\mathrm{Ch}-\mathrm{Cal}\end{array}$ & $\begin{array}{l}\text { 1. } \mathrm{Cc}-\mathrm{Cv}-\mathrm{Dg}-\mathrm{Id}-\mathrm{Bn}-\mathrm{Cu}-\mathrm{Cup}-\mathrm{Tn} r- \\
\mathrm{Mal}-\mathrm{Az}-\mathrm{Lm}\end{array}$ \\
\hline $\begin{array}{l}\text { Вкрапленная, слоистая, конкреции, глобули, } \\
\text { фитоморфозы, зооморфозы } \\
\text { Disseminated, layer, concretion, globules, phyto- } \\
\text { morphoses, zoomorphoses }\end{array}$ & $\begin{array}{l}\text { Просечки, прожилки, гнезда, линзы } \\
\text { Flasers, streaks, nests, lenses }\end{array}$ & $\begin{array}{l}\text { Каёмки, прожилки, псевдоморфозы } \\
\text { Rims, streaks, pseudomorphs }\end{array}$ \\
\hline \multicolumn{3}{|c|}{ Предсудетская зона (верхняя пермь)/Fore-Sudetic zone (Upper Perm) } \\
\hline \multicolumn{2}{|c|}{ 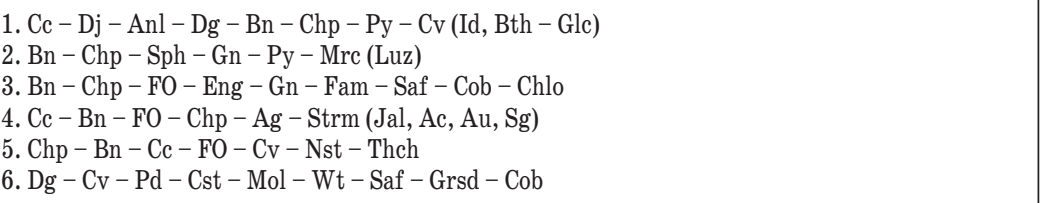 } & $\begin{array}{l}\text { 1. Chp }- \text { Cv }- \text { Bn }- \text { Py }- \text { Tnr }- \text { Dlf }-\mathrm{Mal}-\mathrm{Az}- \\
\text { Cu - Lm - Chrs } \\
\text { 2. Pw - Mlb - Wulf - Kch - Chil } \\
\text { 3. Ann - Ery - Smth - Cer }\end{array}$ \\
\hline $\begin{array}{l}\text { Вкрапленная, слоистая, конкреции, глобули, } \\
\text { фито- и зооморфозы } \\
\text { Disseminated, layer, concretion, globules, phyto- } \\
\text { morphoses, zoomorphoses }\end{array}$ & $\begin{array}{l}\text { Просечки, прожилки, гнёзда, линзы } \\
\text { Flasers, streaks, nests, lenses }\end{array}$ & $\begin{array}{l}\text { Прожилки, каёмки, натёки, присыпки, земли- } \\
\text { стые массы, секреции, кристаллы, псевдомор- } \\
\text { фозы } \\
\text { Streaks, rims, incrustations, powders, earthy } \\
\text { accumulations, secretions, crystals, pseudo- } \\
\text { morphs }\end{array}$ \\
\hline \multicolumn{3}{|c|}{ Заирская зона (венд)/Zaire Zone (Vendian) } \\
\hline $\begin{array}{l}\text { 1. Cc - Dg - Anl - Dj - Bn (Bth, Wt, Au, Ag) } \\
\text { 2. Bn - Chp (Id) - Car - Tnt - Gn (Sph, Ger, Ren, } \\
\text { Ur, Gll, Mol, Ln) } \\
\text { 3. Chp - Py - Gn - Sph - Urph - (Po, Mrc, Asp, } \\
\text { Ctt, Ln) } \\
\text { 4. Py - Jsp }\end{array}$ & $\begin{array}{l}\text { 1. Chp - Bn, Qz - Py (Bth, Gn, Sph) } \\
\text { 2. Bn-Cc-Chp - Qz - Cal } \\
\text { 3. Mgt- Ilm-Chp-Chl } \\
\text { 4. Chp - Bn - Po (Hm, Mgt) } \\
\text { 5. Anl - Chl } \\
\text { 6. Qz-Cal- Py }\end{array}$ & $\begin{array}{l}\text { 1. Cc - Cv нормальный и синий/normal and } \\
\text { blue - Dg - Gt - Id - Mal - Chrs (Cu - Psmal, } \\
\text { Lb) } \\
\text { 2. Mal - Az - Arch - Cer - Rs - Smth - Srcb } \\
\text { 3. Cup - Brch - Chlc - Chrs - Dpt 4. Bcq - Cur - } \\
\text { Urph - Ks (Sg и др. / etc.) }\end{array}$ \\
\hline $\begin{array}{l}\text { Слоисто-вкрапленная, конкреции (?), фрамбои- } \\
\text { ды, фитоморфозы, почки, нодули } \\
\text { Layered-disseminated, concretion (?), framboids, } \\
\text { phytomorphoses, buds, nodules }\end{array}$ & $\begin{array}{l}\text { Прожилки, метасоматические тела, брекчии, } \\
\text { штокверки, гнёзда, просечки, линзы } \\
\text { Streaks, metasomatic bodies, breccias, stock- } \\
\text { works, nests, flasers, lenses }\end{array}$ & $\begin{array}{l}\text { Прожилки, каёмки, корочки, секреции, псев- } \\
\text { доморфозы, землистые массы } \\
\text { Streaks, rims, crusts, secretions, pseudomorphs, } \\
\text { earthy accumulations }\end{array}$ \\
\hline \multicolumn{3}{|c|}{ Замбийская зона (венд)/Zambian Zone (Vendian) } \\
\hline $\begin{array}{l}\text { 1. Cc - Bn (Dg, Car, Ag, Au) } \\
\text { 2. Bn - Chp - Car - Ln - Mol (Sph, Gn, Brn, Cof, } \\
\text { Ur, Wlf) } \\
\text { 3. Chp - Py - (Po, Ml, Ln, Sph, Ur) } \\
\text { 4. Py - Car - Chp } \\
\text { 5. Chp - Bn - Car - Pn кобальтовый } / \text { Pn cobaltic }\end{array}$ & $\begin{array}{l}\text { 1. } \mathrm{Qz}-\mathrm{Cal}-\mathrm{Fsp}-\mathrm{Bn}-\mathrm{Cc}-\mathrm{Chp}(\mathrm{Ur}, \mathrm{Anh}) \\
\text { 2. Bn-Chp - Hm - Mgt } \\
\text { 3. Chp - Py - Po- Mgt - Car - Mus - Chl }\end{array}$ & $\begin{array}{l}\text { 1. } \mathrm{Cc}-\mathrm{Dg}-\mathrm{Cv}-\mathrm{Mal}-\mathrm{Az}-\mathrm{Cu}-\mathrm{Cup} \\
\text { 2. Chrs - Verm - Lm (Chlc), Dpt } \\
\text { 3. Chp }-\mathrm{Bn}-\mathrm{Cc}-\mathrm{Cv}\end{array}$ \\
\hline $\begin{array}{l}\text { Вкрапленная, слоистая, конкреции (?), ополз- } \\
\text { невые и другие долитификационные формы } \\
\text { Disseminated, layer, concretion (?), landslides } \\
\text { and other forms of prelithification }\end{array}$ & $\begin{array}{l}\text { Прожилки, гнёзда, линзы и полосы вдоль кли- } \\
\text { важа и трещин } \\
\text { Streaks, nests, lenses and stripes along the clea- } \\
\text { vage and cracks }\end{array}$ & $\begin{array}{l}\text { Прожилки, каёмки, псевдоморфозы, пластин- } \\
\text { чато-решётчатые формы } \\
\text { Streaks, rims, pseudomorphs, lamellar-lattice } \\
\text { forms }\end{array}$ \\
\hline
\end{tabular}


Примечание: в скобках указаны второстепенные минералы/Note: Minor minerals are shown in parentheses. Coкращения/Abbreviations: Ac-акантит/acanthite, Ag - серебро самородное/native silver, Alg-aльгодонит/algodonite, Anh-aнгидрит/anhidrite, Anl-aнилит/anilite, Ann - аннабергит/annabergite, Antf - антофагосит/antofagosit, Antl-aнmлерum/antlerite, Apt - anamum/apatite, Arch - aypuxaльuиm/aurichalcite, Asp - арсенопирит/arsenopyrite, Atk-amaкалит/atacamite, Au - золото/gold, Az - aзypum/azurite, Bar - барum/barite, Bcq - беккерелит/becquerelite, Bn - борнит/bornite, BnA - борнит аномальный/bornite abnormal, Brch - брошантит/brochantite, Brn - браннерит/brannerite, Bt - биотит/biotite, Bth - бетехтинит/betekhtinite, Btl-боталлакит/botallackite, Bv-биверит-(Cu)/be-

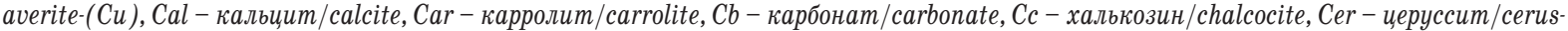
site, Chil - чиллагит/chillagite, Chl - хлорит/chlorite, Chlc - халькантит/chalcanthite, Chlcd - халиедон/chalcedony, Chlo - хлоанmum/chloanthite, Chp - халькопирит/chalcopyrite, Chrs - хризоколла/chrysocolla, Cin - кобальтин/cinnabar, Cob - киноварь/cobaltite,

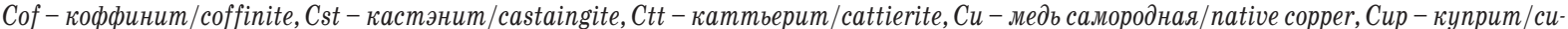

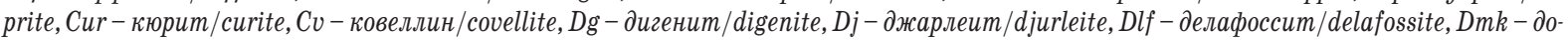
мейкит/domeykite, Dol - доломит/dolomite, Dpt-дuоnтаз/dioptase, Dzh-джезказганит/dzhezkazganite, Eng - энаргит/епаrgite, Ery эритрин/erythrite, FeH - гидроксиды железа/iron hydroxides, Fam - фаматинит/famatinite, Flt - флюорит/fluоrite, FO - блеклые pyды/faded ore, Fsp - полевые шпаты/feldspar, Ger - герланит/germanite, Gl - галенит/galena, Glc - глаукодот/glaucodot, Gll- гaллит/gallite, Grph - гpaфum/graphite, Grsd - герсдорфum/gersdorffite, Gt - гётum/goethite, Gy - zunc/gypsum, Hll - zaллyaзит/halloysite, $\mathrm{Hm}$ - гематит/hematite, Id - uдаum/idaite, Ilm - ильменит/ilmenite, Jal - sлnaum/jalpaite, Jr - spoзит/jarosite, Jsp - яuла/jasper, Kch-кёхлинит/koеchlinite, Khv - ховуаксит/khovuaksite, Ks - казолит/kasolite, Lb - либетенит/libethenite, Lm - лилонит/limonite, Lmp - лампадит /lampadite, Ln - линнеит/linnaeite, Lnr - линарит/linarite, Luz - люцонит/luzonite, Mal - лалахит/malachite, MC минералы шлиха/concentrate minerals, Med-медлонтит/medmontit, Mgt-магнетит/magnetite, Ml- мелонит/melonite, Mlb-лолибdum/molybdite, Mlk - мельниковит/melnikovite, Mlr - миллерит/millerite, Mol - молибденит/molybdenite, Mrc - марказит/marcasite, Mus - мусковит/muskovite, Nntk - нантокит/nantokite, Ntr - нонтронит/nontronite, Nst - нacmypaн/nasturan, Opl - onaл/opal, Pd палладий/palladium, Pl-nлагиоклаз/plagioclase, Pn - пентландum/pentlandite, Po - пирротин/pyrrhotite, Psm - nсиломелан/psilome-

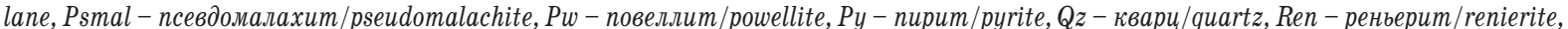

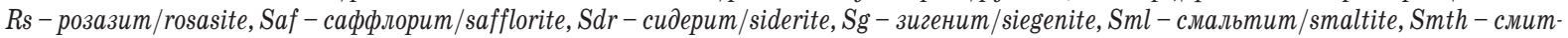
сонит/smithsonite, Sph - cфалерит/sphalerite, Srcb - сферокобальтum/spherocobaltite, Strm - umpoмeйерит/stromeyerite, Thch - myxолит/thucholite, Tnr- тенорит/tenorite, Tnt- теннантит/tennantite, Ur-yранинит/uraninite, Urph-ypaнофан/uranophane, Verm-вермикулит/vermiculite, Wlf-вольфрамит/wolframite, Wt - виттихенит/wittichenite, Wulf-вульфенит/wulfenite, Zrn-uиркон/zircon.

также с пиритом, пирротином и другими минералами.

Карролит теснее всего связан с борнитом (рис. $1, \mu$ ) и халькопиритом, реже - с пиритом, сфалеритом. В целом он относится к редким минералам (Кодаро-Удоканская, Прибайкальская, Французская провинция и зоны), однако в рудах Заир-Замбийского пояса образует промышленные скопления. В этом же поясе кроме карролита установлены другие кобальтовые минералы: каттьерит, кобальтин, линнеит, кобальтовые пентландит и пирит, ассоциирующие с минералами халькопирит-пиритовой зоны: пиритом, халькопиритом, линнеитом, джайпуритом, а через борнит и дигенит и с минералами борнит-халькозиновой зоны [5].

Серебро самородное является сквозным и постоянно присутствующим минералом в рудах почти всех провинций и зон. Глобальная закономерность в размещении этого минерала - приуроченность его главным образом к халькозиновой, реже борнитовой и еще реже халькопирит-пиритовой зоне, где он в виде мелких зерен срастается с минералами указанных зон. Кроме самородной формы серебро проявляется в виде штромейерита, дискразита, полибазита, аргентита и электрума, примерно в тех же минеральных зонах, что и самородное серебро [6].

Pис. 1. Парагенезисы минералов в медистых песчаниках и сланиах, Удокан. Микрофотографии выполнены в отражённом свете. А-В) парагенезисы минералов халькозинового ряда: A) аллотриоморфное выделение дигенита (Dg) в срастании с джарлеитол (Dj) и идиоморфныл кристаллом гелатита $(\mathrm{Hm})$, мартитизированное зерно магнетита (Mgt); Б) сросток борнита (Bn), дигенита (Dg) и джарлеита (Dj). Ковеллин (Cv) замещает дигенит (Dg) и жжарлеит (Dj). Гётит (Gt) в агрегате сульфидов меди в виде прожилковых выделений, по краю - в виде каёлки; B) срастание борнита (Bn), дигенита (Dg) и джарлеита (Dj); парагенезис халькозин-борнит (Cc-Bn) в структурах взаимопроникающих грании и субграфических; Ж-И) борнит-халькопиритовый парагенезис (Bn-Chp) в рудах ледистых песчаников; $K$ ) зернистая структура срастания пирита (Ру) и халькопирита (Chp), по краю сульфидов в виде кайлы образуется ковеллин (Cv); Л, M) порфиробласты пирита (Ру) в срастании с халькопиритом (Chp); H) парагенезис редких минералов в рудах медистых песчаников - карролит (Crr) в халькозине (Cc); О, П) минералы седиментогенного этапа; О) обломочные и новообразованные минералы тяжёлого шлиха в тонком прослое в песчанике: мартит (Mrt) - псевдоморфозы гелатита по магнетиту, ииркон (зональный кристалл), идиоморфные кристаллы порфиробластов магнетита (Mgt); П) замещение окатанных зёрен пирита (Py) гётитом (Gt)

Fig. 1. Mineral paragenesis in cupriferous sandstones and shales, Udokan. Micrographs are taken in reflected light. A-B) paragenesis of chalcocite minerals; $A$ ) anhedral grain of digenite $(\mathrm{Dg})$ with djurleite $(\mathrm{Dj})$ and euhedral crystal of hematite $(\mathrm{Hm})$, magnetite $(\mathrm{Mgt})$ grain partly replaced and rimmed by hematite; $B$ ) accretion bornite $(\mathrm{Bn})$, digenite $(\mathrm{Dg})$ and djurleite $(\mathrm{Dj})$. Covellite (Cv) replaces digenite $(D g)$ and djurleite $(D j)$. Goethite $(G t)$ is within the aggregate of copper sulfides in the form of streaky secretions and on the edge in the form of a rim; $B$ ) accretion of bornite (Bn), digenite ( $D g$ ) and djurleite ( $D j) ; \Gamma-E$ ) chalcocite-bornite (Cc-Bn) paragenesis in the structures of interpenetrating and subgraphic boundaries; $Ж-И)$ bornite-chalcopyrite paragenesis (Bn-Chp) in cupriferous sandstone ores; $K)$ granular structure of the accretion of pyrite $(\mathrm{Py})$ and chalcopyrite $(\mathrm{Chp})$. Covellite $(\mathrm{Cv})$ is formed along the edge of the sulfides as a border; $J, M)$ pyrite porphyroblasts (Py) in accretion with chalcopyrite (Chp); $H$ ) paragenesis of rare minerals in the ores of cupriferous sandstones - carrolite ( $\mathrm{Crr}$ ) in chalcocite ( $\mathrm{Cc}$ ); $\mathrm{O}, \Pi)$ minerals of the sedimentary stage; 0$)$ detrital and newly formed heavy minerals in a thin interlayer in sandstone: martite (Mrt)-hematite pseudomorphs on magnetite, zircon (zonal crystal), euhedral crystals of magnetite porphyroblasts $(\mathrm{Mgt})$; $\Pi$ ) replacement of rounded pyrite grains $(\mathrm{Py})$ by goethite $(\mathrm{Gt})$ 
Золото самородное в отдельных месторождениях и провинциях (Сибирская платформа, ГабонАнгольская зона, Заир-Замбийский пояс и др.) образует мелкие изометричные и таблитчатые зерна, связывается большей частью с минералами борнитхалькозиновой зоны, хотя отмечается также в пирит-халькопиритовой. Может вообще в свободном виде встречаться в цементе вмещающих пород, обрастать каемкой вторичного золота или находиться вместе с минералами тяжелого шлиха: апатитом, турмалином, цирконом, магнетитом и др.

\section{Этапы формирования парагенезисов}

В своем длительном развитии руды медистых песчаников и их вмещающие породы прошли этапы седиментогенеза, диагенеза, катагенеза, метаморфиз-
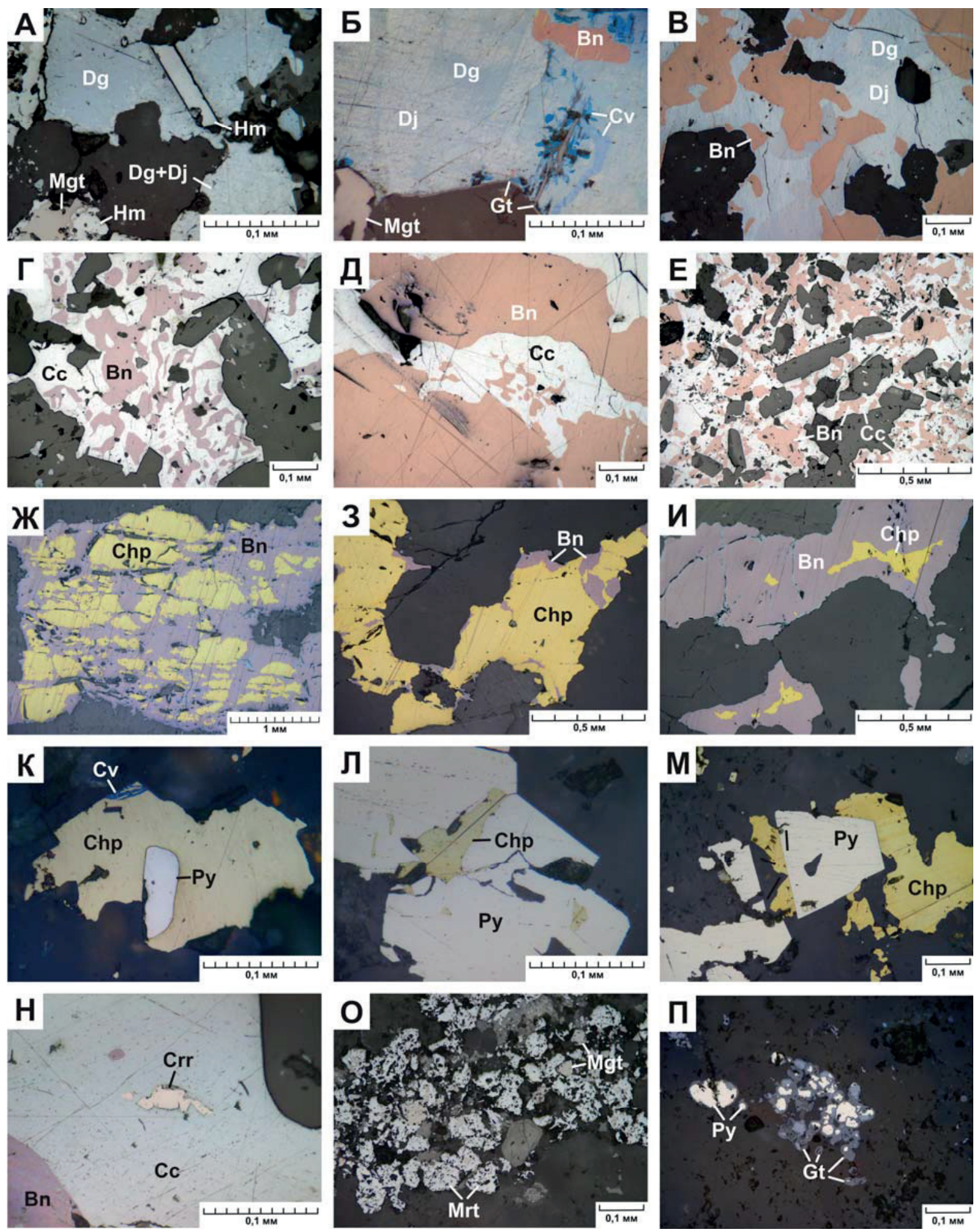
ма [7-12] В большинстве случаев некоторые процессы начинаются в один этап, развиваются и продолжаются в следующем, захватывая иногда и третий этап. С другой стороны, есть явления, которые достаточно уверенно характеризуют тот или иной процесс или этап. Например, минералы естественного тяжелого шлиха в форме слойков или обломков достоверно фиксируют седиментогенный этап; мала- хит, азурит, гидрооксиды железа и марганца, замещающие сульфиды в близповерхностных местах, могут быть отнесены к гипергенному этапу.

Нами предпринята попытка на основе морфологических особенностей, текстурно-структурных взаимоотношений рудных и породообразующих минералов и некоторых других признаков проследить этапы формирования парагенезисов минералов.
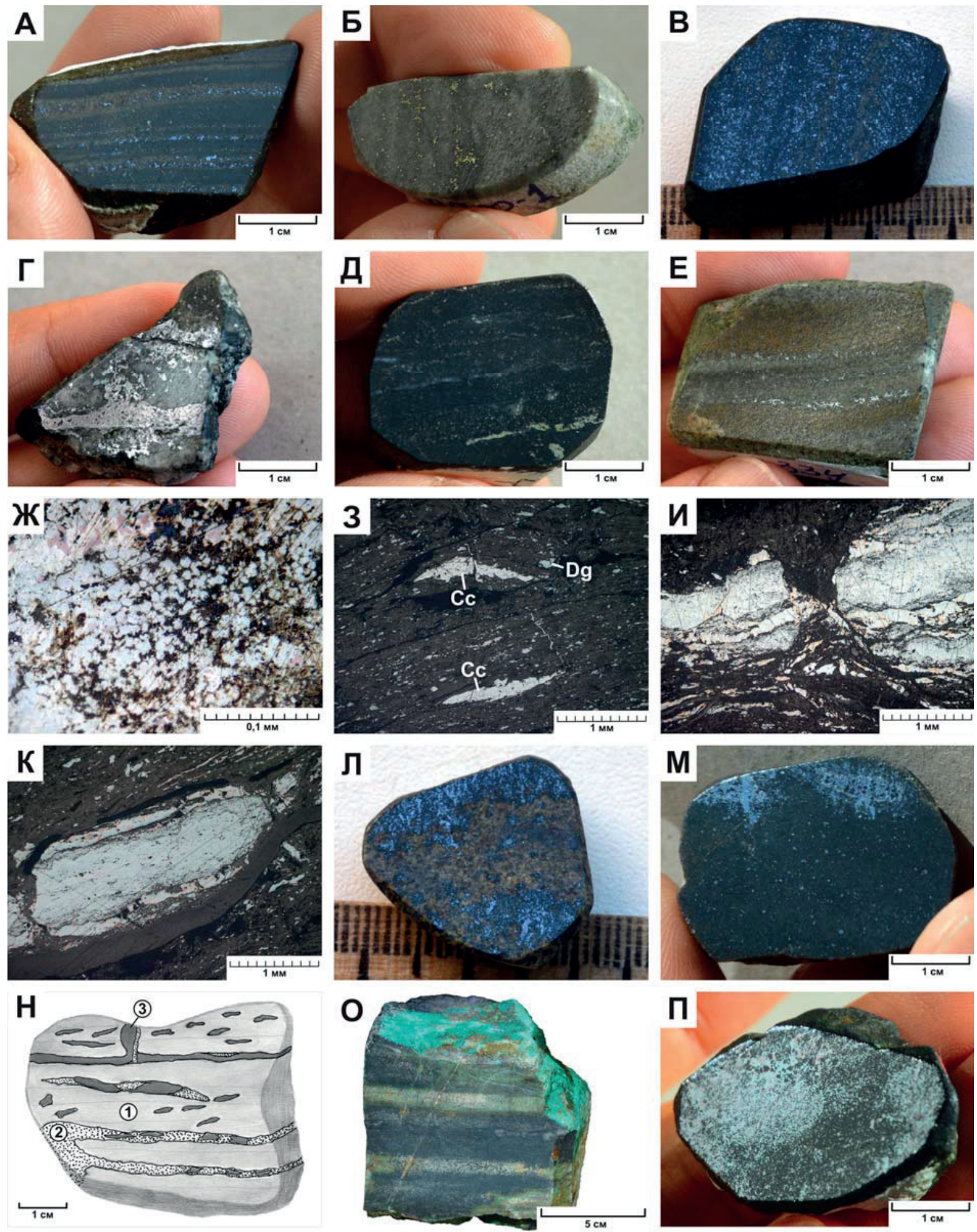
Для седиментащионной стадии характерен парагенезис минералов естественного шлиха (рис. 1, o): гематит, магнетит, мартит, ильменит, турмалин, апатит, циркон, золото, сфен и др., подчиняющиеся в своем распределении в осадках законам механической дифференциации с формированием слойков различных типов, мощности и протяженности. В песчаниках среди обломков породообразующих минералов: кварца, полевых шпатов и пород в очень многих формациях, встречается редкая вкрапленность зерен пирита, халькопирита, изредка халькозина, блеклых руд, борнита (рис. $1, n$ ). В отдельных случаях наблюдались слойки, сложенные пиритом, которые в большинстве своем лимонитизированы, окатаны, сильно изменены, что связано с процессами изменения во время транспортировки. Все названные минералы приносились в бассейны седиментации совместно с терригенным материалом и являются прямыми указателями областей питания. Имеются примеры большого сходства типоморфных признаков минералов, встреченных в рудоносных горизонтах и в предполагаемых областях питания [11-14]. К седиментогенным относятся аутигенные минералы, формирующиеся в растворах и илах: кальцит, анальцим, доломит, малахит, азурит, а также, возможно, сульфаты меди и других металлов, участвующих в рудообразовании. Для этого этапа весьма характерны окислительные условия с нейтральными и щелочными средами накопления компонентов [14].

K седиментационно-диагенетическому этапу относится образование различных слоистых форм парагенезисов: горизонтальных, волнистых, косых и др. Слойки могут быть сложены одним мине- ралом, например халькопиритом, борнитом или пиритом, но чаще всего такими парами, как: борнит и халькозин, борнит и халькопирит, борнит и галенит, галенит и сфалерит, пирит и халькопирит и др. (рис. $2, a-e$ ).

В седиментогенезе закладываются контуры рудоносных залежей, их ритмичное положение в разрезе вмещающих толщ, зональное размещение минералов и элементов в залежах в зависимости от $\mathrm{pH}$ среды и фациальной обстановки $[4,9,11,14,15]$. Седиментогенные парагенезы формируются в условиях невысоких температур (до $30^{\circ} \mathrm{C}$ ) и давлений - около 1-2 атм. [4].

Диагенез наряду с седиментогенезом является основным рудообразующим этапом, в течение которого происходит формирование сульфидов и других минералов в форме вкрапленности, слойков, сгустков, гнезд, псевдоморфоз, глобулей и др. Весьма характерны для диагенетического этапа конкреционные образования [4]. Они представляют собой, по существу, густовкрапленные образования рудных минералов на фоне бедной и рядовой рудной минерализации. Состав их самый разнообразный, но, как правило, многокомпонентный. Они слагаются практически теми же минералами, что и другие более крупные по размерам рудные залежи. Форма конкреций, их состав, размеры, внутреннее строение, взаимоотношения с вмещающими отложениями, условия формирования детально рассмотрены в работах $[10,16-19]$ и представлены здесь на рис. $2, \ldots-\kappa$.

В истории формирования конкреций можно выделить несколько стадий, или этапов. Первым является седиментационный, когда из наддонной

Pис. 2. Формы выделения парагенезисов рудных минералов: А-В) слоистые руды Удоканского месторождения: А) песчаник со слоистостью, подчёркнутой халькопирит-дигенит-борнитовыми вкрапленниками; Б) рудные слойки с вкрапленностью халькопирита в песчанике; В) Песчаник с густовкрапленными борнит-дигенитовыми слегка размытыми слоями; $\Gamma-E)$ слоистые формы главных парагенезисов (борнит-халькозин-халькопирит) седиментационно-диагенетического этапа, Удокан: $\Gamma$ ) слойки и конкреиионные сгущения борнит-дигентовой минерализации; Д) ритлично-полосчатое чередование борнита (голубоватое) и халькопирита (светло-жёлтое); E) тонкая ритмичная слоистость, подчеркнутая сульфидами меди; Ж) конкреиионно-глобулярные формы сульфиов в медных рудах - шарообразные борнит-дигенит-халькозиновые глобули (зооморфозы по микробал), Шахта «Рудная», Польша; 3-К) формы выделения халькозина в рудах, шахта «Рудная», Польша: 3) вкрапленность и линзовидные выделения халькозина и дигенита в углистом сланце; И) слоисто-конкреционная форма борнит-дигенит-халькозинового парагенезиса в углистом слание; К) фитоморфоза сульфидов меди по растительной ткани; ЛI-H) текстуры руд постдиагенетических этапов: Л ) слоисто-гнездово-прожилковая текстура сульфидов меди, Удокан; М) гнездово-линзовидная текстура сульфидов меди, Удокан; Н) прожилково-просечковая текстура, Витимский район: 1 - полосчатый биотитовый песчаник, 2 - квариевый прожилок, 3 - халькопирит; О, П ) текстуры богатых борнит-дигенит-халькозиновых руд Удоканского месторождения, образованных в результате перераспределения в постдиагенетические этапы: 0) чередование сплошных (тёмное) и обеднённых борнит-халькозиновых прослоев; П) гнездовые сгущения борнита и дигенита на фоне их слоисто-вкрапленных форм

Fig. 2. Forms of recognition of paragenesis of ore minerals: $A-B$ ) layered ores of Udokan deposit: A) sandstone with layer underlined by chalcopyrite-digenite-bornite impregnations; $B$ ) ore layers with chalcopyrite impregnation in sandstone; $B$ ) sandstone with slightly blurred densely disseminated bornite-digenite layers; $\Gamma-E$ ) layered forms of the main parageneses (bornite-chalcocite-chalcopyrite) of sedimentation-diagenetic stage, Udokan: $\Gamma$ ) layers and concretion thickening of bornite-digenite mineralization; Д) rhythmically banded alternation of bornite (bluish) and chalcopyrite (light yellow); $E$ ) fine rhythmic layers, underlined by copper sulfides; Ж⿱一𫝀) concretion-globular forms of sulfides in copper ores - spherical bornite-digenite-chalcocite globules (zoomorphoses on microphores), «Rudnaya» mine, P0land; $3-K$ ) forms of allocation of chalcocite in ores, mine «Rudnaya», Poland: 3 ) disseminated and lens recognitions of chalcocite and digenite in coal shale; $И$ ) layer-concretion form of a bornite-digenite-chalcocite paragenesis in coal shale; $K$ ) phytomorphoses of copper sulphides on plant fossils; JI-H) ores textures of post-diagenetic stages: J) layered nesting-streak texture of copper sulfides, Udokan; $M$ ) nesting-lenses texture of copper sulfides, Udokan; $H$ ) streak-flaser texture, Vitimsk region: 1 - banded biotite sandstone, 2 - quartz streak, 3 - chalcopyrite; $0, \Pi$ ) textures of rich bornit-digenite-chalcocite ores from the Udokan deposit, formed as a result of redistribution on the post-diagenetic stages: 0 ) alternation of massive (dark) and depleted bornite - chalcocite interlayers; $\Pi$ ) nest thickenings of bornite and digenite on the background of their layered-disseminated forms 
воды происходит выпадение конкрециообразователя, зарождаются отдельные центры роста конкреций у самой поверхности дна. Основной этап конкрециеобразования приходится на диагенез, в течение которого формируются сульфиды, карбонаты и другие минералы. Примером типичных диагенетических конкреций являются сульфидные конкреции Джезказганского района, детально описанные в работах В.М. Попова [12] и Л.Ф. Наркелюна [13]. Процессы катагенеза и метаморфизма приводят к перераспределению вещества в самих конкрециях, изменению свойств и появлению новых минералов. По-видимому, катагенетическим минералом следует считать гематит в составе конкреций, а такие минералы, как ильменит, магнетит, пирротин, некоторые группы силикатов, необходимо отнести к метаморфогенным. На стадии гипергенеза образуются малахит-азуритовые, брошантит-антлеритовые, купритовые и мелантеритовые конкреции.

К диагенетическим образованиям, видимо, можно отнести мелкие зерна, кристаллы и ажурные пористые скелетные агрегаты рудных минералов, располагающиеся по слоистости, несущие слабые признаки коррозии цемента и обломков и по своим размерам соответствующие зернам вмещающих пород.

На диагенетическое образование минералов указывают признаки нарушения рудной слоистости и напластования в незатвердевшем осадке, выявленные на многих объектах, но особенно детально изученные на Удоканском и Джезказганском месторождениях [12, 13, 15]. На Удокане, например, широко развиты осадочные брекчии взламывания, оползания и облекания, рулетободобные колобки рудоносных осадков, оползневые деформации рудной слоистости. На Джезказгане ко всем этим признакам добавляются кластические дайки. Сильно деформированные оруденелые слойки перекрываются горизонтальными слоями красноцветов. Все это свидетельствует о том, что оруденение уже существовало на самых ранних этапах образования осадков [15].

Необходимо также указать, что в неизмененных формациях рудные минералы имеют ненарушенную внутреннюю структуру: в борните, пирите можно наблюдать концентрически-зональное строение гелевого вещества, структуры усыхания геля и др. В преобразованных рудах диагенетические минералы подвергаются различным изменениям $[9,18]$.

Конкретные примеры парагенезисов минералов седиментационно-диагенетического этапа формирования приведены в таблице.

При диагенезе происходит перевод седиментационных карбонатно-окисных форм металлов в сульфиды; идёт перераспределение седиментогенного рудного вещества с формированием вкрапленности, конкреций, глобул, сгущений, линз, пластов различного масштаба - от проявлений до месторождений; рудообразование осуществляется в восстановительной обстановке двумя путями: а) в тонкозернистых осадках (сланцах) - из поровых вод в форме ионов и по слоям; б) в грубозернистых осадках (песчаниках) - за счет миграции рудоносных растворов из тонкозернистых осадков при их литификации и отложении полезного груза на «восстановительных барьерах», которыми в большинстве случаев является захороненная органика $[3,4,7,11,12,20]$.

В постдиагенетические этапы (катагенез и метаморфизм) происходят изменения, которые сводятся к следующему:

- рудное вещество вместе с вмещающими отложениями участвует во всех процессах преобразования, перекристаллизации, деформации, перемещения и т. д.;

- появляются вновь образовавшиеся минералы, которые, взаимодействуя с ранее сформированными минералами, дают начало новым парагенезисам;

- происходит формирование жил и прожилков, включающих в себя практически все имеющиеся минералы вмещающих толщ, в том числе и рудные;

- отмечается карбонатизация терригенного материала, окремнение и эпидотизация карбонатных пород; окварцевание, декальцитизация и др. $[7-9,11,15,18,19,21]$.

Эти и некоторые другие процессы постдиагенетических преобразований рассматриваются ниже в кратком виде.

Первое, что бросается в глаза, - это появление новых форм выделения минералов: крупных гнезд, линз, сгущений массивных сульфидных полос, просечек, прожилков, агрегатов на фоне вкрапленности и слоистости (рис. $2, \pi-n, 3)$. Такие формы могли появиться только в результате взаимодействия последующих процессов перераспределения, главными факторами которых выступают повышенные температуры и давление. Учитывая, что состав крупных вновь образованных форм почти идентичен таковому слоисто-вкрапленных руд, а также исчезновение рудных минералов около указанных сгущений, можно считать, что все эти процессы происходили в результате перераспределения исходного материала и отложения его на месте. Подобные преобразования наблюдались нами при изучении образцов Мангышлака, Джезказгана, многих сибирских рудопроявлений и особенно в Кодаро-Удоканской и Кондо-Каренгской зонах.

Наблюдения под микроскопом показывают, что в ряде случаев на ранее выделившихся минералах появляются вновь образованные каемки (новые генерации) или происходит замещение одного минерала другим. Особенно это хорошо заметно при изучении пирита, иногда и других минералов.

При постдиагенетических преобразованиях минералы подвергаются перекристаллизации и различным деформациям. На катагенетической стадии такие изменения наблюдаются в конкрециях: появление секущих прожилков, признаков 
A

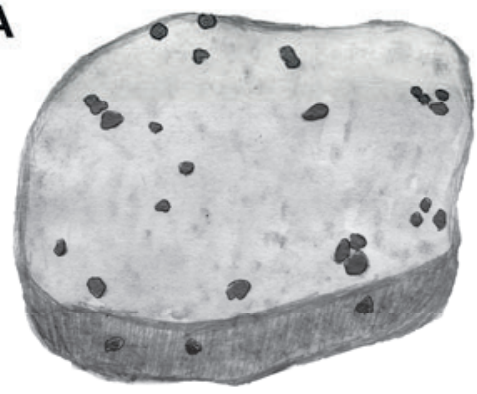

$\Gamma$

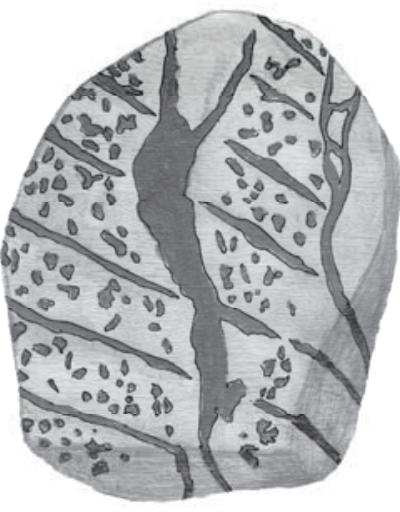

Б

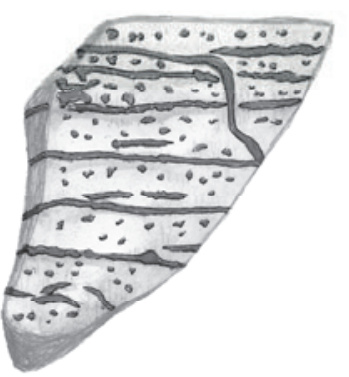

B

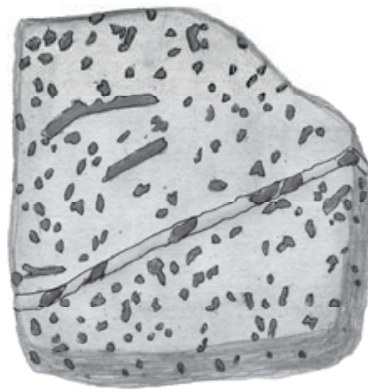

д

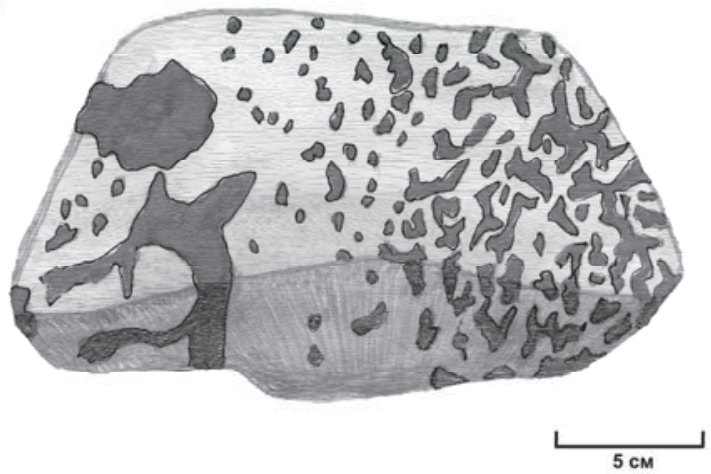

Рис.3. Халькопириты Ункурского месторождения: А) вкрапленность округлых зерен в массивном розоватом песчанике, скв. 118, обр. у-625; Б) расположение густой вкрапленности халькопирита по слоистости, видны салые начальные стадии образования просечек, $у$-488; В) образование отдельных укрупненных зерен, просечек и появление халькопирита в квариевом прожилке на фоне вкрапленности халькопирита в розоватом песчанике, $y-580 ; \Gamma$ ) форлирование секущих просечек и прожилков халькопирита с неровныли краяли на фоне его слоисто-вкрапленных выделений в розовом мелкозернистом песчанике, отчетливо прослатривается исчезновение вкрапленности халькопирита у его просечек, окраска песчаника в этих безрудных зонах более светлая, у-720; Д) образование гнезд халькопирита на фоне его вкрапленности в розоватом песчанике, видно отсутствие халькопирита вблизи гнезд, $y-456$

Fig. 3. Chalcopyrites of Unkur deposit: A) impregnation of rounded grains in the massive pink sandstone, drill 118, sample u-625; 5 ) pattern of location of thick impregnation with chalcopyrite by layering; the initial stages of flaser formation are seen; B) formation of individual enlarged grains, flasers and appearance of chalcopyrite in pinkish sandstone; $\Gamma$ ) formation of crossing flasers and veinlets of chalcopyrite showing irregularedges on the background of its layer-impregnated separations in the pink fine-grained sandstone; impregnation of chalcopyrite near its flasers disappears, coloring of sandstone in these ore-devoid zones is lighter, u-720; Д) formation of chalcopyrite nests on the background of its impregnation in pinkish sandstone, chalcopyrite is absent near nests, $u-456$

сдавливания, дробления и т. п. Во вкрапленных рудах проявляются более заметные признаки замещения и коррозии не только обломков, но и цемента вмещающих пород, «захват» рудным веществом породообразующих компонентов. По мере увеличения степени вторичных преобразований нарастают и механические изменения в рудных минералах: хрупкие и пластические деформации, появление структур перекристаллизации, двойников давления и смятия. Также увеличивается степень эпигенетичности рудных минералов. Наиболее эпигенетичными оказываются пластичные и мягкие минералы: халькозин, борнит и халькопирит, у хрупких и твердых минералов (пирит, магнетит, сфалерит) степень эпигенетичности меньше. Под давлением более хрупкий минерал дробится, а более пластичный вдавливается в него и залечивает трещинки. Это хорошо заметно на примере таких пар минералов, как: пирит-халькопирит, пирротин-халькопирит; халькопирит-халькозин; магнетит-борнит с халькозином и др. На основе характера деформаций, значения величин хрупкости-пластичности, определенных по методу В. Глазова и В. Вигдоровича, основные рудо- и породообразующие минералы удается расположить в следующий ряд (по уменьшению пластичности и увеличению хрупкости): халькозин-борнит-кальцит-халькопирит, сфалерит-пирротин-гематит-магнетит-пирит-кварц-силикаты $[15,18]$.

На основе сопоставления оруденения из месторождений и проявлений, находящихся на различных ступенях преобразований, удается наметить появление характерных минералов на той или иной стадии, например, гематита за счет гидроокислов железа при катагенезе, а пирротина, магнетита, ильменита, графита, халькопирита - при метаморфизме [7, 10, 11, 14, 18, 21].

Новообразованный гематит отмечается в виде крупных и мелких лапчатых зерен, пластинок, табличек, которые замещают и корродируют обломки, цемент вмещающих пород, включает в себя мелкие зерна сульфидов (рис. $4, a-8$ ). Многие исследователи (Р.Н. Володин, Ю.В. Богданов, 
Л.Ф. Наркелюн, Н.С. Мануилова) считают, что образование гематита происходит за счет гидроксидов железа, рассеянных по всей массе вмещающих пород $[11,13]$. Под микроскопом прослеживаются многие этапы формирования гематита, выраженные в появлении различных его форм. Вначале в поле развития гидроксидов железа появляется мелкая сыпь, далее тонкие иглы, волнистые агрегаты, пластинки, таблички. С постепенным ростом зерен гематита идет исчезновение гидроксидов железа. Такие процессы наблюдались нами на Прибайкальских, Приангарских рудопроявлениях, на Ункуре; Н.С. Мануиловой - на Джезказгане $[18,62]$. Ассоциация со многими сульфидами: бор-
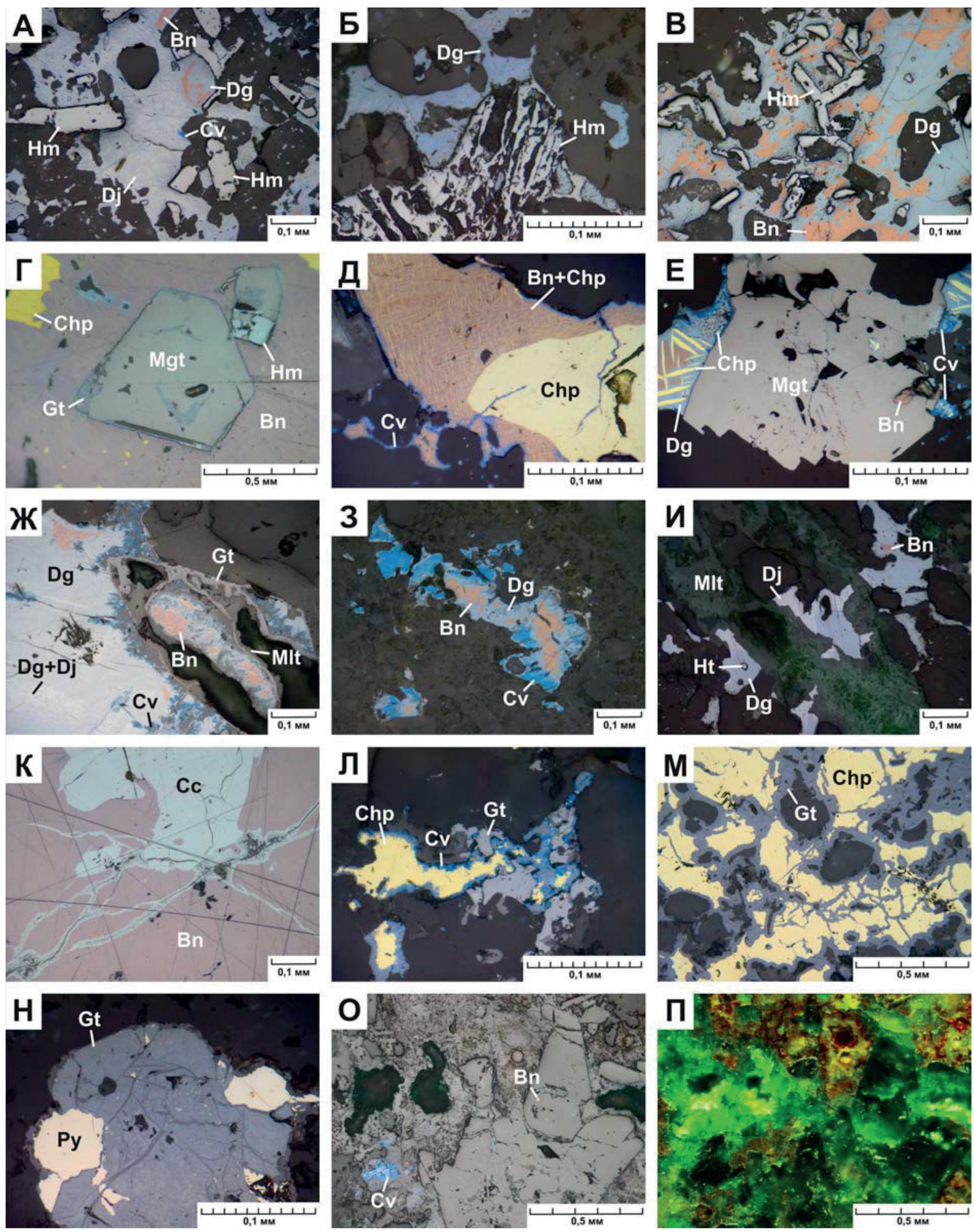
нитом, халькозином, халькопиритом, структурные взаимоотношения (рис. $4, a-8$ ) свидетельствуют о более позднем формировании гематита по сравнению с диагенетическими минералами и близкоодновременном с катагенетическими. Гематит очень «охотно» образуется в различных жилах: в слабоизмененных формациях он тяготеет к кальцитовым, а в метаморфизованных - чаще к кварцевым и кварц-силикатным жилам.

Пирротин в качестве второстепенного и редкого минерала установлен в ряде меденосных провинций и зон. Наибольшее свое развитие имеет в метаморфизованных рудах Кодаро-Удоканской зоны. Он образует рассеянную вкрапленность и просечки, срастается с халькопиритом, графитом, арсенопиритом, миллеритом, сфалеритом и другими минералами. С пиритом у пирротина сложные взаимоотношения: они могут быть тесно сросшимися и близко-одновремеными, чаще пирит замещается пирротином, иногда в пирротине появляются порфиробласты пирита. Подобные взаимоотношения объясняются влиянием температуры, давления, режимом и летучестью серы, имевших место при различных стадиях метаморфизма $[22,23]$. К метаморфогенным процессам можно отнести появление порфиробластов и метакристаллов пирита в халькопирите и тем более пирротине, отмеченных в рудах Кодаро-Удоканской зоны, Айнакского и некоторых других месторождений (рис. 1, м).

Новообразованный магнетит, в отличие от об- ломочного, встречающийся в виде вкрапленности идиоморфных зерен октаэдрического габитуса или неправильной формы, многими авторами считается сформированным при метаморфизме за счет гидроксидов железа и гематита (Р.Н. Володин, Ю.В. Богданов, Л.Ф. Наркелюн, Ф.П. Кренделев и др.) $[7-9,11]$. Наибольшее свое развитие этот магнетит имеет в метаморфизованных медистых песчаниках Кодаро-Удоканской, Кондо-Каренгской, Заир-Замбийской [32], Кабульской зон. Во взаимоотношениях магнетита с сульфидами намечается их близко-одновременное формирование, а чаще всего более позднее выделение магнетита по отношению к сульфидам в форме метакристаллов (рис. 4,2 ) или окружающей каемки. На примере Кодаро-Удоканских образцов нами установлено, что наибольшее количество новообразованного магнетита отмечается в борнит-халькозиновых рудах, несколько меньше в борнитовых и совсем мало в пирит-халькопиритовых. Подобное зональное размещение количеств магнетита, образовавшегося за счет гидроксидов и оксидов железа, объясняется различным уровнем окислительно-восстановительного потенциала [24]. В некоторых случаях на контакте с метакристаллами магнетита в борните появляются пластинки и зерна халькопирита, образование которого происходит за счет дополнительного источника железа. Это явление хорошо изучено на многих месторождениях и описано А. Филимоновой, В.П. Логиновым и др. [8].

Pис. 4. Парагенезисы минералов в медистых песчаниках и сланиах, удокан: A-B) парагенезы минералов катагенетического этапа: А) идиоморфные кристаллы и аллотриоморфные зёрна гематита (Hт) в ассоциации с сульфидами меди: борнитом (Вп), дигенитом (Dg), джарлеитом (Dj), ковеллином (Cv), Удокан; Б) сноповидные зёрна гематита в парагенезисе с дигенитом; В) тесная ассоциация гематита (рельефное) и сульфидов меди-идиоморфные кристллы и зёрна гелатита (Нт) в ассоциации с борнитом (Bn) и дигенитм (Dg); Г) метаморфогенный парагенезис минералов: борнит-халькопирит-магнетит в медистых песчаниках - метакристалл магнетита (Mgt) в борните (Bn). Магнетит замещается гётитол (Gt) и гематитом (Hm). Xалькопирит (Chp); Д, Е) структуры распада твёрдого раствора: халькопирит-борнит в медных рудах: Д) тончайшая решетка халькопирита (Chp) в борните (Bn). Ковеллин (Cv) в виде каёмки замещает первичные сульфиды меди; E) сгущение (коалесцениия) халькопирита (Chp) и борнита (Bn) в дигените (Dg) на контакте с новообразованныл (метаморфогенныл) магнетитом (Mgt); Ж-И) замещение сульфидов меди гипергенными минералали: Ж) Замещение борнита (Bn) дигенитол (Dg), джарлеитом (Dj), ковеллином (Cv), гётитом (Gt) и малахитом (Mlt); 3) замещение борнита (Bn) дигенитом (Dg) и ковеллином (Cv); И) залещение борнита (Bn) дигенитом (Dg), джарлеитом (Dj), малахитом (Mlt); $K, \mathrm{I})$ структуры залещения: K) замещение борнита (Bn) халькозином (Cc); Л) прожилки и каёмки ковеллина (Cv) и гётита (Gt) по халькопириту (Chp); M-П) развитие гидроксидов железа и карбонатов меди по сульфидал: M) Замещение халькопирита (Chp) гётитол (Gt); H) псевдоморфоза гётита (Gt) по пириту (Py); O) псевдоморфоза гидроксидов железа и карбонатов меди по сульфидам меди. Борнит (Bn), ковеллин (Cv); П) то же, что и на рис. 4, О, только при боковом освещении. Внутренние рефлексы гидроксидов железа (оранжево-коричневые) и карбонатов меди (зелёные)

Fig. 4. Paragenesis of minerals in the cupriferous sandstones and shales, Udokan: A-B) paragenesis of minerals of catagenetic stage: A) euhedral crystals and anhedral grains of hematite $(\mathrm{Hm})$ in association with the copper sulfides: bornite (Bn), digenite (Dg), djurleite (Dj), covellite ( $\mathrm{Cv})$, Udokan; $B$ ) reap-like grains of hematite in paragenesis with digenite; $B$ ) close association of hematite (relief) and copper sulphides - euhedral crystals and hematite grains $(\mathrm{Hm})$ in association with bornite (Bn) and digenite (Dg); $\Gamma$ ) metamorphogenic paragenesis of minerals: bornite-chalcopyrite-magnetite in cupriferous sandstones - magnetite metacrystal (Mgt) in bornite (Bn). Magnetite is replaced by goethite (Gt) and hematite ( $\mathrm{Hm}$ ). Chalcopyrite (Chp); Д, E) solid solution decomposition structures: chalcopyrite-bornite in copper ores: Д) thinest chalcopyrite lattice ( $\mathrm{Chp}$ ) in bornite $(\mathrm{Bn})$. Covellin ( $\mathrm{Cv}$ ) in the form of a rim replaces the primary copper sulfides; $E$ ) condensation (coalescence) of chalcopyrite (Chp) and bornite (Bn) in digenite (Dg) on contact with newly formed (metamorphogenic) magnetite (Mgt); $\nVdash-H)$ replacement of copper sulphides with hypergene minerals: $\nVdash$ ) replacement of bornite $(\mathrm{Bn})$ with digenite $(\mathrm{Dg})$, djurleite $(\mathrm{Dj})$, covellite $(\mathrm{Cv})$, goethite $(\mathrm{Gt})$ and malachite $(\mathrm{Mlt}) ; 3)$ replacement of bornite (Bn) with digenite $(\mathrm{Dg})$ and covellite $(\mathrm{Cv}) ; \mathrm{H})$ replacement of bornite $(\mathrm{Bn})$ with digenite $(\mathrm{Dg})$, djurleite $(\mathrm{Dj})$, malachite $(\mathrm{Mlt}) ; \mathrm{K}$, $\mathrm{J})$ structure of replacement: $K$ ) replacement of bornite $(\mathrm{Bn})$ with chalcocite $(\mathrm{Cc}) ; \mathrm{I})$ streaks and rims of covellite $(\mathrm{Cv})$ and goetite (Gt) replaces chalcopyrite (Chp); $M-\Pi$ ) sulphides replaced by iron hydroxides and copper carbonates; $M$ ) replacement of chalcopyrite (Chp) with goethite (Gt); $H$ ) pseudomorphs goethite (Gt) on pyrite (Py); O) pseudomorphs of iron hydroxides and copper carbonates on copper sulfides. Bornite (Bn), covellite ( $\mathrm{Cv}) ; \Pi)$ same as in Fig. 4, O, only with side lighting. Internal reflexes of iron hydroxides (orange-brown) and copper carbonates (green) 
Ассоциация магнетита с халькопиритом и пиритом отмечается не только в метаморфизованных рудах медистых песчаников, но также и на многих колчеданных месторождениях, претерпевших региональный метаморфизм в условиях от зеленосланцевой до амфиболитовой фаций [23]. Главными термодинамическими факторами образования указанных ассоциаций по А. Маракушеву [25] являются: температура, активность кислорода и серы. К метаморфогенным процессам относятся: появление таких ассоциаций, как магнетит-ильменит, титаномагнетит, распад твердых растворов ильменит-гематит, сфалерит-халькопирит, халькопирит-борнит [18, 26].

Весьма характерным процессом постдиагенетических этапов преобразования всех меденосных формаций является появление жильных образований «альпийского типа» $[7-11,14,27]$. Как показывает сравнительный материал, в катагенетически измененных меденосных формациях формируются жилы гипсового, кальцитового, флюоритового, баритового, кварц-кальцитового и реже кварцевого состава. Из сульфидов в этих жилах появляются только те, которые отмечены во вмещающих толщах, нередок в них и гематит. Данные минералотермического и декрипитационного анализа указывают на низкие температуры формирования жильных минералов от 45-60 до $150-220{ }^{\circ} \mathrm{C}$, соответствующие преобразованиям пород и руд в условиях катагенеза от начального до глубинного [10, 11, 27]

При метаморфизме продолжается формирование жил альпийского типа в меденосных формациях. На примере изучения жил Удоканского и некоторых других месторождений Кодаро-Удоканской зоны нами установлено, что можно наметить следующий порядок образования жил: кальцитовые-кварц-кальцитовые-кварцевые-кварц-силикатные, соответствующие стадиям катагенеза, peгионального и контактового метаморфизма. Все без исключения жилы при пересечении ими рудоносных горизонтов содержат в себе сульфиды меди, по преобладанию которых выделяются халькозиновые, борнитовые, халькопиритовые, а также гематитовые жилы. Изредка в жилах в метаморфический этап появляется магнетит.

Наличие в жилах и во вмещающих их породах одних и тех же рудных и нерудных минералов свидетельствует об унаследованности химизма вмещающих толщ и развивающихся в них жильных образований. Устанавливается также общность жильных минералов и минералов вмещающих пород по элементам-примесям [6]. Парагенезисы минералов из жил даже в деталях соответствуют таковым из вкрапленных руд. Изучение взаимоотношений жил с вмещающими породами, структурнотекстурные соотношения минералов в жилах позволяют высказать предположение, что часть альпийских жил в меденосных формациях образуется метасоматическим путем (нечеткие контакты с вмещающими породами, сохранение в жилах тек- стурных признаков вмещающих пород, неопределенное положение рудных минералов в жилах и др.) либо путем заполнения катагенетическими и метаморфогенными растворами открытых полостей (четкие контакты жил с вмещающими породами, зональное расположение минералов относительно контактов жил, параллельно-шестоватые агрегаты и т. п.). Можно встретить жилы, образованные обоими вышеуказанными способами одновременно. Температура образования минералов из метаморфических жил колеблется в пределах $230-350{ }^{\circ} \mathrm{C}$, иногда до $400{ }^{\circ} \mathrm{C}[10]$.

K контактовому метаморфизму отнесены следующие изменения: смена текстур руд от вкрапленно-слоистой (вдали от контактов) через гнездовые, полосчатые, линзовидные до прожилковой (у контакта с дайками); образование локальной зональности оруденения и обогащение зальбандов даек медью за счет ассимиляции ее из вмещающих пород; появление структур распада твердого раствора: халькопирита и борнита (рис. $4, \partial, e)$, сфалерита в халькопирите и халькопирита в сфалерите; изменение физических свойств минералов (микротвердость, внутренние структуры и др.). Характер метаморфических изменений основных рудообразующих минералов проверен экспериментально нами на примере образцов из Удокана и Джезказгана [10], М.К. Сатпаевой [28] и И.Ф. Габлиной [29] на рудах Джезказгана. В результате этих опытов установлено интенсивное дробление всех рудных минералов, причем чем тверже и хрупче минерал, тем сильнее степень дробления. В халькозине и реже борните появляются также пластические деформации. Нарушаются структурные взаимоотношения минералов, отмечено в нескольких опытах образование халькопирита по борниту и пирита на контакте магнетита с медными минералами, происходит растворение халькозина и дигенита в борните в интервале температур $150-250{ }^{\circ} \mathrm{C}$. Из оранжевых борнитов при $190-195{ }^{\circ} \mathrm{C}$ начинает выделяться халькопирит в форме линзочек и округлых зерен, при $220-250{ }^{\circ} \mathrm{C}$ происходит укрупнение включений халькопирита, при 400-500 ${ }^{\circ} \mathrm{C}$ отмечаются эвтектоидные халькопирит-борнитовые срастания и жилочки самородной меди. Весьма близкие изменения (кроме эвтектоидных структур и прожилков самородной меди) мы наблюдали в медных рудах Клюквенного рудопроявления на контакте с гранитоидами Кеменской интрузии. Температуры контактового метаморфизма достигали $500{ }^{\circ} \mathrm{C}[9,10,14]$.

Парагенетические ассоциации минералов постседиментационных этапов в меденосных зонах и провинциях приведены в таблице. В целом же можно отметить, что парагенезы минералов этих этапов в значительной мере наследуют таковые диагенетических процессов, но в то же время появляются свои специфические ассоциации, присущие только, скажем, катагенезу или метаморфизму.

Гипергенный этап характеризуется формированием своих парагенетических ассоциаций и 
форм их выделения (таблица). На начальной стадии гипергенного этапа происходит замещение первичных сульфидов меди ковеллином и халькозином с образованием каемчатых и жильных текстур (рис. $4, a, \partial-3, \kappa, л)$, что обусловлено зоной вторичного сульфидного обогащения. На поздних стадиях гипергенного этапа самые распространенные минералы зон окисления - малахит, азурит и гидроксиды железа, замещают все медные сульфиды (рис. $4, ж, u, л-n)$. При этом образуются прожилковые, каемчатые, раскрошенные, петельчатые, псевдоморфные и другие текстуры и структуры. Самые распространенные минералы зон окисления - малахит, азурит и гидроксиды железа, которые замещают все медные сульфиды (рис. $4, \varkappa_{-n}$ ) с образованием прожилковых, каемчатых, раскрошенных, петельчатых, псевдоморфных и других текстур и структур. В рудах месторождений Кодаро-Удоканской зоны выявлено формирование пластинчато-решетчатых форм халькопирита в зоне окисления за счет замещения борнита халькозином (рис. $5, a$ ), халькопирита борнитом (рис. $5, \sigma, 6)$, борнита халькопиритом (рис. 5, 2).

По разнообразию и составу окисленные руды, пожалуй, не уступают первичным, поскольку в них развиты карбонаты, сульфаты, оксиды, ги- дроксиды, силикаты, фосфаты, сульфиды, арсенаты, молибдаты и др. [2].

В формировании зон окисления устанавливается несколько стадий развития, характеризующихся набором своих специфических минеральных парагенезисов и довольно сложной последовательностью минералообразования. Анализ имеющихся материалов свидетельствует, что развитие процессов гипергенеза зависит от ряда факторов: тектонически-структурные особенности месторождения, литологический и минеральный состав вмещающих отложений и первичных руд, условия залегания рудных тел, рельеф местности на месторождении, климатические условия, текстурноструктурные особенности руд и др. [2]. Особенностями зоны окисления Удокана являются: а) обратная стадийность в формировании главных минеральных парагенезисов по сравнению с классическими медными месторождениями; б) формирование гипергенных минералов в условиях многолетнемерзлых пород и минералогическая зональность (снизу вверх): первичные сульфиды с примесью до 5-30 \% гипергенных минералов - сульфатов, карбонатов, окислов и гидроокислов; в) вторичные сульфиды со значительной примесью (до 30-90 \%) всех гипергенных минералов, особенно сульфатов и карбонатов. Эту вторую (верхнюю) зо-
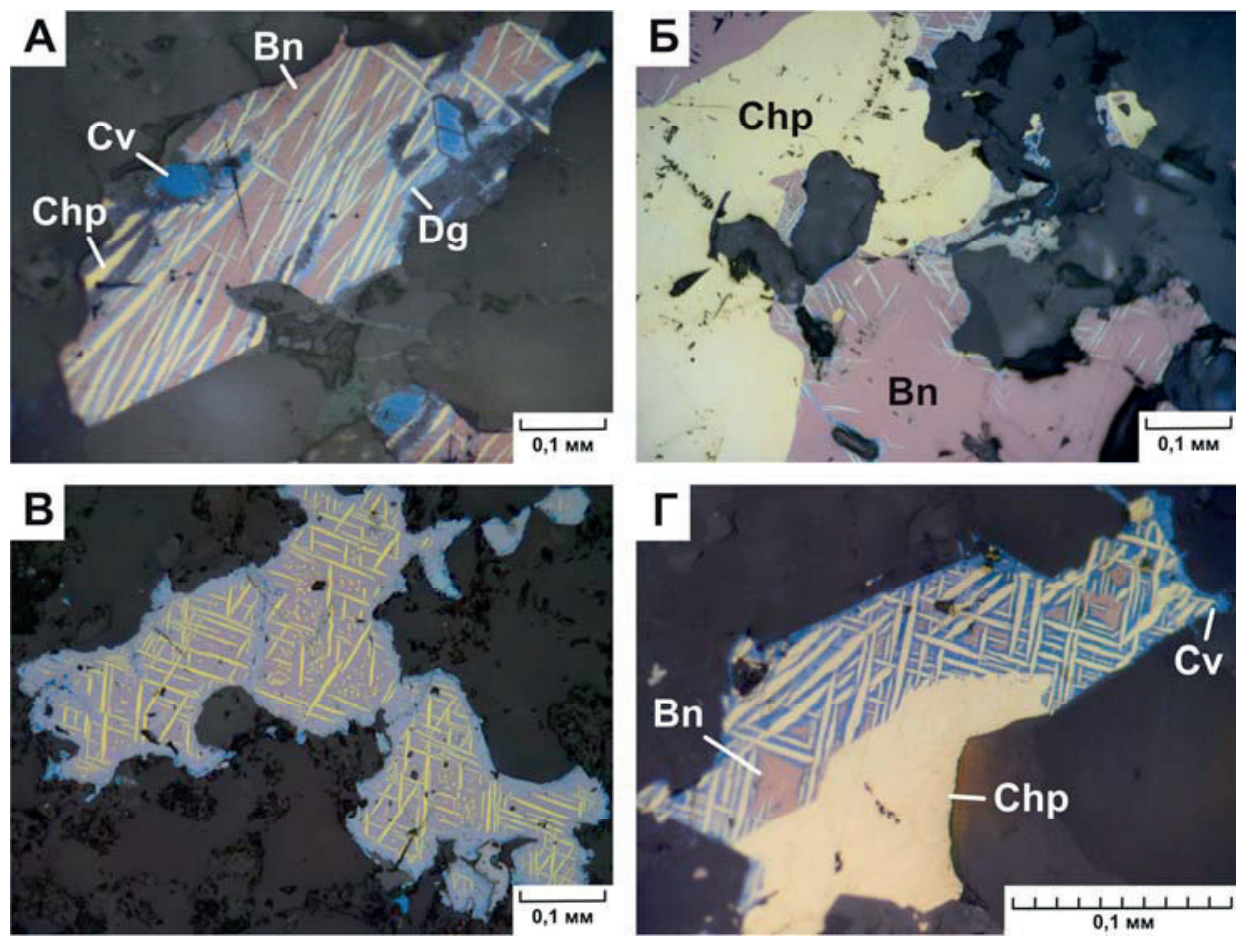

Puс. 5. Решетчатые структуры распада борнита в рудах Удоканского месторождения, возникшие в зоне окисления. Конечные продукты распада борнита (Bn): халькопирит (Chp), дигенит ( $\mathrm{Dg})$, ковеллин (Cv).A) пластинчатый халькопирит, образованный при распаде твёрдого раствора борнита; Б, В) образование пластинчато-решетчатого халькопирита при распаде борнита: Б) начальная стадия; В) конечная стадия; Г) образование решетчатой структуры при замещении борнита халькопиритом

Fig. 5. Latticed structures of bornite decomposition in ores of the Udokan deposit derived in the zone of oxidation. Final products of bornite $(\mathrm{Bn})$ decomposition: chalcopyrite (Chp), digenite $(\mathrm{Dg})$, covellite $(\mathrm{Cv})$. A) lamellar chalcopyrite formed in decomposition of solid solution of bornite; $5, B)$ formation of lamellar-latticed chalcopyrite in bornite decomposition: 5 ) initial stage; $B$ ) final stage; $\Gamma$ ) formation of latticed structure through replacement of bornite with chalcopyrite 
ну в какой-то мере можно отнести к своеобразной зоне вторичного обогащения [2, 18], в которой наряду с ковеллинизацией халькозина и халькозинизацией борнита и отчасти халькопирита происходит формирование в широких масштабах реакционно-пластинчатого халькопирита со структурами типа «распада твердых растворов» [26], мартитизация магнетита, хлоритизация биотита, монтмориллонитизация слоистых силикатов [2].

Геолого-минералогические и технологические исследования, проведенные на Удокане, позволили выделить три сорта руд: сульфидные, смешанные и окисленные, в распределении которых установлены следующие контролирующие факторы:

1) гипсометрический - зональное вертикальное размещение сортов руд сверху вниз: окисленные-смешанные-сульфидные;

2) тектонический - проникновение окисленных и смешанных типов руд по зонам тектонической трещиноватости на значительные глубины;

3) литологический - приуроченность карбонатов меди к известковистым, а сульфатов - к кварцитовидным песчаникам;

4) минералогический - развитие определенных парагенезисов гипергенных минералов по первичным рудам;

5) климатический - двухстадийное формирование зон окисления в зависимости от климата, существовавшего при формировании зон окисления. В настоящее время считается доказанным, что образование минералов в криолитозоне подтверждается многими факторами [11, 30-32], которые очень активно действуют практически во всех горизонтах мерзлой толщи. Поэтому сульфаты меди и других металлов развиты очень широко на Удокане и других месторождениях Кодаро-Удоканской зоны.

\section{Выводы}

1. В рудах месторождений медистых песчаников и сланцев по условиям формирования выделены седиментационно-диагенетические, постдиагенетические, гипергенные, а по степени распространения главные, второстепенные и редко встречающиеся парагенезисы минералов. К главным парагенезисам отнесены срастания основных рудообразующих минералов - группы халькозина, борнита, халькопирита, пирита. Их структурные срастания и расположение в рудных телах показывают, что все они образуют парные или промежуточные тройные или более сложные парагенезисы и сформировались более или менее одновременно, но в разных частях 30нального ряда. Парагенезисы второстепенных и редких минералов характеризуются тесным срастанием с основными рудообразующими и приуроченностью их к определенным мине- ральным зонам. Сравнение общего списка парагенезисов минералов, проведенное по всем известным объектам, показывает, что в своей основной массе главные парагенезисы схожи, различие намечается по второстепенным и редковстречающимся парагенезисам.

2. Формы выделения минералов и парагенезисов, их размеры являются важными диагностическими признаками. Различные слоистые, мелковкрапленные, конкреционно-глобулярные формы отнесены к седиментационно-диагенетическим образованиям; прожилковые, полосчатые, пятнистые, гнездово-линзовидные, просечковые, брекчиевидные, массивные являются текстурами перераспределения, возникшими при катагенезе и метаморфизме; порошковато-землистые, натечные, корковые, псевдоморфные текстуры характерны для гипергенного этапа.

3. Минералы и их парагенезисы своим составом, морфологией, параметрами, структурными взаимоотношениями отражают сложную геологическую историю развития и условия формирования оруденения медистых песчаников и сланцев. Установленная эволюция парагенезисов проявляется:

- в седиментогенезе: формированием и распределением рудоносных осадков в зависимости от $\mathrm{pH}$, карбонатности, фациальной обстановки, климата, подчиняющихся законам механической и химической дифференциации и ритмичности-цикличности;

- диагенезе: образованием слоистых, вкрапленных, конкреционных форм сульфидов, оформлением рудных залежей и минералогической зональности в зависимости от Eh-pH среды рудообразования, растворимости сульфидов, концентрации металлов, сульфат-ионов и сероводорода;

- катагенезе и метаморфизме: появлением наряду с медными сульфидами гематита, магнетита, графита, пирротина, ильменита, титаномагнетита, силикатов; возникновением на фоне слоисто-вкрапленных выделений просечковых, прожилковых, массивных форм парагенезисов, свидетельствующих о решающей роли повышенных температур и давлений, метаморфогенных растворов в этих процессах и происходящих в пределах ранее сформированных рудных залежей;

- гипергенезе: широким развитием реакций окисления и восстановления с формированием разнообразных структур замещения вплоть до образования полных псевдоморфоз, которые зависят от многих факторов климата, рельефа, тектоники, литологического и минерального состава руд. 


\section{СПИСОК ЛИТЕРАТУРЫ}

1. Бродин Б.В. 0 парагенезисе минералов (к дискуссии о сущности и объеме понятия) // Изв. Вузов. Геол. и разведка. 1981. - № 7. - С. 41-46.

2. Окисленные руды Удокана / Л.Ф. Наркелюн, А.И. Трубачев, В.С. Салихов и др. - Новосибирск: Наука, 1987. - 101 с.

3. Лурье А.М. Генезис медистых песчаников и сланцев. - М.: Недра, 1988. - 183 с.

4. Страхов Н.М. Основы теории литогенеза. - М.: АН СССР, 1962. - T. 2. -575 c.

5. Annels A.E., Vaughan D.J., Craig J.R. Conditions of ore mineral formation in Zambian copper belt deposite with special reference to the role of cobalt // Mineralium deposita. - 1983. - V. 18. № 1. - P. 71-88.

6. Безродных Ю.П. Распределение и условия накопления серебра, золота и других элементов-примесей в медистых песчаниках и сланцах: автореф. дис. ... канд. геол.-минерал. наук. Иркутск, 1969. - 23 с.

7. Стратифицированные месторождения меди СССР / Ю.В. Богданов, Е.З. Бурьянова, Э.И. Кутырев и др. - Л.: Недра, 1973. 312 c.

8. Удоканское медное и Катугинское редкометалльное месторождения Читинской области России / Р.Н. Володин, В.С. Чечеткин, А.И. Трубачев и др. - Чита: Поиск, 2004. - 522 с.

9. Кренделев Ф.П., Бакун Н.Н., Володин Р.Н. Медистые песчаники Удокана. - М.: Наука, 1983. - 248 с.

10. Медистые песчаники и сланцы южной части Сибирской платформы / Л.Ф. Наркелюн, Ю.П. Безродных, А.И. Трубачев, В.С. Салихов. - М.: Недра, 1977. - 223 с.

11. Наркелюн Л.Ф. Геология и оруденение Джезказганского месторождения. - М.: Наука, 1962. - 131 с.

12. Попов В.М. Пластовые месторождения цветных металлов и вопросы их генезиса // Проблемы генезиса руд. - М.: Наука, 1964. - C. 350-368.

13. Наркелюн Л.Ф. Геология и оруденение Джезказганского месторождения. - М.: Наука, 1962. - 131 с.

14. Богданов Ю.В. Контактовый метаморфизм медистых песчаников в районе Удоканского месторождения // Записки ВМ0. 1963. - Т. 92. - № 5 - С. 535-546.

15. Наркелюн Л.Ф., Трубачев А.И. Индикаторы осадочного формирования стратиформных месторождений меди // Литогенез и рудообразование. - М.: Наука, 1989. - С. 64-78.

16. Корольков А.Т., Радомская Т.А., Ягуджиньский Р. Генезис польских месторождений меди // Известия Иркутского государственного университета. Серия «Науки о Земле». - 2016. T. $17 .-$ C. $91-102$.

17. Genetic models of formation of cupriferous sandstone and shale deposits (examples from Jezkazgan, Udokan and the Lubin Gìgów Copper District) / A.I. Trubachev, A.T. Korolkov, A. Duchmal-Chernikiewicz, T.A. Radomskaya // Petrological and mineralogical studies in geology: VIII Polish Conference. Abstrakts. - Crakow, Poland, 1-2 June 2017. - P. 53.

18. Трубачев А.И. Формационно-парагенетический анализ медистых песчаников и сланцев, закономерности их размещения и генезис. - Чита: ЧитГУ, 2009. - 347 с.

19. Трубачев А.И., Салихов В.С., Васильев В.Г. Стратиформные месторождения Забайкалья. - Чита: ЗабГУ, 2014. - 305 с.

20. Габлина И.Ф. Условия меденакопления в красноцветных континентальных формациях. - М.: Наука, 1983. - 111 с.

21. Домарев В.С. Особенности разновозрастных месторождений медистых песчаников // Пробл. минерал. и петрологии. - Л.: Наука, 1972. - С. 147-158.

22. Белевцев Я.Н. Метаморфогенное рудообразование. - М.: Недра, 1979. - 275 с.

23. Ручкин Г.В. Модель регионального метаморфизма докембрийских колчеданных месторождений // Геол. рудн. мест-ний. 1981. - № 5. - C. 19-32.
24. Гаррельс Р.М., Крайст Ч.Л. Растворы, минералы, равновесия. - М.: Мир, 1968. - 368 с.

25. Маракушев А.А. Термодинамическая основа образования парагенезисов химических элементов в процессах глубинного минералообразования // Очерки физико-химической петрологии. - М.: Наука, 1975. - Вып. 5. - С. 121-194.

26. Безродных Ю.П., Наркелюн Л.Ф., Трубачев А.И. 0 структурах типа распада твердого раствора в рудах Удоканского месторождения // Тр. Иркутск. политехн. ин-та. - Иркутск: ИПИ, 1968. - Вып. 42. - С. 135-144.

27. Салихов В.С. Условия образования и структурно-вещественные особенности стратиформного медного оруденения. - Чита: ЧитГУ, 2008. - 377 с.

28. Сатпаева М.К. Руды Джезказгана и условия их формирования. - Алма-Ата: Наука, 1985. - 208 с.

29. Габлина И.Ф. Метаморфизм и гипергенез медистых песчаников и сланцев: автореф. дис.... д-ра геол.-минерал. наук. - М., 1994. -45 c.

30. Питулько В.М. Вторичные ореолы рассеяния в криолитозоне. Л.: Недра, 1977.-198 с.

31. Юргенсон Г.А., Безродных Ю.П. 0 зоне окисления Удоканского месторождения меди и ее роли в формировании температурного поля многолетнемерзлых пород // Геокриологич. условия Забайкальского Севера. - М.: Наука, 1966. - С. 53-55.

32. Юргенсон Г.А., Гаврилов А.М., Ильменев Е.С. Минералы кобальта месторождения меди Айнак // Записки ВМ0. - 1985. Вып. 4. - С. 428-434.

33. Мендельсон Ф. Медный пояс Северной Родезии. - М.: ИЛ, 1963. $-474 \mathrm{c}$.

34. Аман А., Соловьев Н.Н. Стратиформное месторождение меди Айнак (Афганистан) и главнейшие критерии его прогноза // Стратиформные месторождения. - Чита: ЧитПИ, 1982. C. $100-109$.

35. Annels A.E., Vaughan D.J., Craig J.R. Conditions of ore mineral formation in Zambian copper belt deposite with special reference to the role of cobalt // Mineralium deposita. - 1983. - V. 18. № 1. - P. 71-88.

36. A multistage origin for Kupferschiefer mineralization / D.H.M. Alderton, D. Selby, H. Kucha, D.J. Blundell // Ore Geol. Rev. - 2016. - V. 79. - P. 535-543.

37. Tracking redox controls and sourses of sedimentary mineralization using copper and lead isotopes / D. Asael, A. Matthews, M. Bar-Matthews, Y. Harlavan, I. Segal // Chemical Geology. 2012. - V. 310-311. - P. 23-35.

38. Brown A.C. Close linkage of copper (and uranium) transport to diagenetic reddening of "upstream» basin sediments for sedimenthosted stratiform copper (and roll-type uranium) mineralization // Journal of Geochemical Exploration. - 2006. - V. 89. - № 1-3. P. 23-26.

39. Sediment-hosted stratiform copper deposits / R.W. Boyle, A.C. Brown, C.W. Jefferson, E.C. Jowett, R.V. Kirkham. - Ottawa: Geological Association of Canada, 1989. - V. 36. - Special paper. $-710 \mathrm{p}$.

40. Chmielewski A., Oszczepalski S., Speczik S. Relict mineralization in the transition zone, Kupferschiefer series of SW Poland // W: Mineral resources in a sustainable world / Ed. by A.S. AndreMayeriin. - Nancy: Universite de Lorraine. Proceedings, 2015. V. 5. - P. 1897-1900.

41. Dziewińska L., Tarkowski R. Geophysical study of deep basement structure of NW Poland using effective reflection coefficients // C. R. Geosci. - 2016. - V. 348. - P. 587-597.

42. A new insight on the results of geophysical research of the ForeSudetic area in terms of prospecting for mineral deposits / L. Dziewińska, A. Pepel, R. Tarkowski, Z. Zuk // Biuletyn Państwowego Instytutu Geologicznego. - 2017. - V. 468. - P. 165-174.

43. Experimental study of the copper isotope fractionation between aqueous $\mathrm{Cu}$ (II) and covellite, CuS / S. Ehrlich, I. Butler, L. Ha- 
licz, D. Rickard, A. Oldroyd, A. Matthews. Chemical Geology. 2004. - V. 209. - № 3-4. - P. 259-269.

44. Handbook of strata-bound and stratiform ore deposits. V. 6. Cu, $\mathrm{Zn}, \mathrm{Pb}$, and Ag Deposits / Ed. by K.H. Wolf. - Amsterdam: Elsevier, 1976. $-573 \mathrm{p}$.

45. Harańczyk C. Petrography classification of the Zechstein copperbearing rocks from Silesia // Bull. Acad. Polon. Sci. Geol. Geogr. - 1964. - V. 12. - № 12. - P. 19-25.

46. Harańczyk C., Jarosz J. Mineraly kruszcowe zloza miedzi monokliny Przedsudeckiei // Rudy I Metale niezelazne. - 1973. R. 18. - № 10. - P. 398-493.

47. Hitzman M.W., Selley D., Bull S. Formation of sedimentary rockhosted stratiform copper deposits through earth history // Economic Geology. - 2010. - V. 105. - № 3. - P. 627-639.

48. Konstantynowich E. Mineralizacia utworow cechstynu nieki polnochsudeckiej. - Warczawa: Wydawnictwo Geologiczne, 1965. $84 \mathrm{p}$.

49. Kozub-Budzyń G.A., Piestrzyński A. Geochemical characteristic of Ag-bearing minerals occurring in copper ore deposit at the Fore-Sudetic Monocline // Biuletyn Państwowego Instytutu Geologicznego. - 2017. - V. 468. - P. 49-60.

50. Król P., Sawlowicz Z. Massive copper sulphide mineralization in dolomites from the Lubin mine (Fore-Sudetic Monocline) // Biuletyn Państwowego Instytutu Geologicznego. - 2017. - V. 468. P. 29-48.

51. Kucha H. Pt-group in Cu-deposits Poland // Ecom. Geol. 1982. - № 6. - P. 1578-1591.

52. Kucha H. Precious metal bearing shale from Zechstein copper deposits, Lower Silesia Poland // Trans. Inst. Mining and Met. 1983. - B. 92. - P. 72-79.

53. Kucha H., Bil B.W. The characteristics of ore mineralization in the Weisswasser copper district, Germany // Biuletyn Państwowego Instytutu Geologicznego. - 2017. - V. 468. P. $143-152$.

54. Cu isotopic fractionation in the supergene environment with and without bacteria / R. Mathur, J. Ruiz, S. Titley, L. Liermann, H. Buss, S. Brantley // Geochimica et Cosmochimica Acta. 2005. - V. 69. - № 22. - P. 5233-5246.

55. Mikulski S.Z., Stein H.J. Re-Os ages for Ag-bearing Cu sulphide ores from the Kupferschiefer in Poland // Proceeding of the $13^{\text {th }}$ Biennial SGA Meeting. - Nancy, France, 24-27 August 2015. Nancy: Université de Lorraine, 2015. - P. 607-610.

56. Oszczepalski S., Chmielewski A., Speczik S. Variability of ore mineralization in the North-West-trending extension of the LubinSieroszowice deposit // Biuletyn Państwowego Instytutu Geologicznego. - 2017. - V. 468. - P. 109-142.

57. Prospective copper resources in Poland. Gospodarka Surowcami Mineralnymi / S. Oszczepalski, S. Speczik, K. Ma£ecka, A. Chmielewski // Mineral Resources Management. - 2016. V. 32. - № 2. - P. 5-30.
58. Experimental study of $\mathrm{Cu}$ isotope fractionation during the reaction of aqueous $\mathrm{Cu}$ (II) with $\mathrm{Fe}$ (II) sulphides at temperatures between 40 and $200{ }^{\circ} \mathrm{C} / \mathrm{M}$. Pakala, D. Asael, I.B. Butler, A. Matthews, D. Rickard, M. Pækala // Chemical Geology. 2011. - V. 289. - № 1-2. - P. 31-38.

59. Relationship between the occurrence of ore minerals and geochemical properties of organic matter in the Kupferschiefer strata, KGHM Polska miedź S.A. mining area / J. Pieczonka, D. Wiælaw, A. Piestrzyński, M.J. Kotarba, R. Rożek, R. Jedlecki, W. Szarowski, M. Wlodarczyk // Biuletyn Państwowego Instytutu Geologicznego. - 2017. - V. 468. - P. 9-28.

60. Geology of the European Kupferschiefer, Lubin, Poland / A. Piestrzyński, J. Pieczonka, T. Ćwiertnia, W. Zygo // Geological Excursion Guide, $13^{\text {th }}$ Biennial SGA Meeting. - Nancy, France, 24-27 August 2015. - $51 \mathrm{p}$.

61. Radliński M., Sawìwwicz Z. Altered rhythmic sulphide bands in the Weissliegens sandstone in the Rudna mine (Fore-Sudetic Monocline, Poland) / / Biuletyn Państwowego Instytutu Geologicznego. - 2017. - V. 468. - P. 61-78.

62. Sokalska A. Zmienność litologiczna lupku miedzionośnego w obniżeniach reliefu biaìgo spagowca w rejonie zò̀ż rud miedzi Rudna i Sieroszowice // Biuletyn Państwowego Instytutu Geologicznego. - 2017. -V. 468. - P. 199-208.

63. Stein H.J. Dating and Tracing the History of Ore Formation // Treatise on Geochemistry. $2^{\text {nd }}$ ed. / Ed. by H.D. Holland, K.K. Turekian. - 0xford: Elsevier, 2014. - V. 13. - P. 87-118.

64. Mikulski S.Z., Stein H.J. Re-Os isotopic age of the Cu-Ag sulphide ore and its mineralogical and geochemical characteristic from the Lubin-Polkowice mining area (SW Poland) // Biuletyn Państwowego Instytutu Geologicznego. - 2017. - V. 468. P. 79-96.

65. Genetic models of formation of cupriferous sandstone and shale deposits (examples from Jezkazgan, Udokan and the Lubin Glogów Copper District) / A.I. Trubachev, A.T. Korolkov, A. Duchmal-Chernikiewicz, T.A. Radomskaya // Petrological and mineralogical studies in geology: VIII Polish Conference. Abstrakts. - Crakow, Poland, 1-2 June 2017. - P. 53.

66. Vaughan D.J. Sulfide mineralogy and geochemistry: introduction and overview // Reviews in Mineralogy and Geochemistry. 2006. - V. 61. - P. 1-5.

67. Mass fractionation processes of transition metal isotopes / X.K. Zhu, Y. Guo, R.J.P. Williams et al. // Earth and Planetary Science Letters. - 2002. - V. 200. - № 1-2. - P. 47-62.

68. Zieliński K., Speczik S. Deep copper and silver deposits - a chance for Polish metal mining industry // Biuletyn Państwowego Instytutu Geologicznego. - 2017. - V. 468. - P. 153-164.

69. Zweeney M.A., Binda P.L., Vaughan D.J. Genesis of the ores of the Zambian copper belt // Ore geok. rev. - 1991. - V. 6. - № 1. P. 51-76.

Поступила 27.08.2019 2.

\section{Информация об авторах}

Трубачев А.И., доктор геолого-минералогических наук, профессор кафедры обогащения полезных ископаемых и вторичного сырья Забайкальского государственного университета.

Корольков A.T., доктор геолого-минералогических наук, профессор кафедры динамической геологии Иркутского государственного университета.

Радомская T.A., кандидат геолого-минералогических наук, научный сотрудник Института геохимии им. А.П. Виноградова СО РАН. 
UDC 553.2:553.434

\title{
PARAGENESES OF MINERALS AND FORMS OF THEIR RECOGNITION REFLECTING THE STAGES OF FORMATION OF CUPRIFEROUS SANDSTONES AND SHALES DEPOSIT
}

\author{
Aleksey I. Trubachev', \\ jesika-m@yandex.ru
}

\author{
Aleksey T. Korolkov², \\ baley51@mail.ru

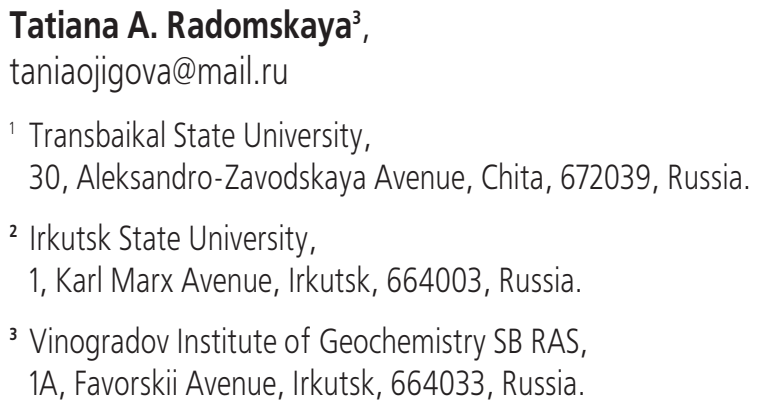

The relevance of the research. The views on the genesis of cupriferous sandstones and shales deposits have been widely discussed in subject-related literature. Even if diverse research approaches are available, the study on the parageneses of major ore minerals of deposits remains the main criterion for credibility of proposed hypotheses.

The main aim of the research is to reveal the stages of formation of cupriferous sandstones and shales deposits using acquired data on the relationships between major ore minerals.

Objects: deposits and ore occurrences of cupriferous sandstones and shales deposits of the Kodar-Udokan zone and comparative analysis of the obtained results on the other 74 Cu-bearing zones.

Methods: geological survey for uncovering the setting, conditions of formation, specifics of structure, mineral composition of deposits and ore occurrences of cupriferous sandstones and shales, mineragraphy research of major ore minerals parageneses.

Results. It was found that ore of the cupriferous and sandstones and shales deposits contains numerous minerals, which when merged, produce paragenetic associations subdivided into major, secondary and rare, and considering formation conditions classified as sedimentation-diagenetic, post-diagenetic and hypergenic ones. The minerals display diverse structural relationships (lamellar, lattice-like, counter-penetrating boundaries, subgraphic, replacements, granule, corrosion, porphyroblastic, etc.). The mostly common forms of recognizing individual minerals and their parageneses are: disseminated, spot, layer (parallel, rhythmically layered, wavy, oblique), concretionglobule, streak, rim, lens, nest, flaser, colloform, earth-powder and incrustations, reflecting the main stages for rock and ore formation of cupriferous and sandstones and shales deposits: sedimentogenesis-diagenesis-catagenesis-metamorphism-hypergenesis. Formation of minerals, their parageneses and forms of recognition are defined in sedimentogenesis by: $\mathrm{pH}$ value, carbonate media, lithology-facies setting, climate; in diagenesis: values of Eh and pH media of ore formation, solubility of sulfides, concentration of metals, sulphateions and $\mathrm{H}_{2} \mathrm{~S}$; in catagenesis and metamorphism: increased temperatures and pressures, action of metamorphic and post-magmatic solutions; in hypergenesis: reactions of oxidation and reduction, electrochemical and bacterial processes dependent on hypsometry, tectonics, lithologic features, climate, mineral composition of primary ores.

\section{Key words:}

Cupriferous sandstones and shales deposits, paragenesis of minerals, structure, texture, forms of recognition, stages, conditions of formation.

\section{REFERENCES}

1. Brodin B.V. 0 paragenezise mineralov (k diskussii o sushchnosti i obeme ponyatiya) [0n the paragenesis of minerals (to the discussion about the essence and scope of the concept)]. Izvestiya vuzov «Geologiya i razvedka», 1981, no. 7, pp. 41-46.

2. Narkelyun L.F., Trubachev A.I., Salikhov V.S. Okislennye rudy Udokana [0xidized ores of Udokan]. Novosibirsk, Nauka Publ., $1987.101 \mathrm{p}$.

3. Krendelev F.P., Bakun N.N., Volodin R.N. Medistye peschaniki Udokana [Copper sandstones of Udokan]. Moscow, Nauka Publ., $1983.248 \mathrm{p}$.

4. Strakhov N.M. Osnovy teorii litogeneza [Fundamentals of the theory of lithogenesis]. Moscow, USSR Academy of Sciences Publ., 1962. Vol. 2, $575 \mathrm{p}$.

5. Annels A.E., Vaughan D.J., Craig J.R. Conditions of ore mineral formation in Zambian copper belt deposite with special reference to the role of cobalt. Mineralium deposita, 1983, vol. 18, no. 1, pp. 71-88.

6. Bezrodnykh Yu.P. Raspredelenie i usloviya nakopleniya serebra, zolota $i$ drugikh elementov-primesey $v$ medistykh peschanikakh $i$ slancakh. Avtoreferat Kand. nauk [Distribution and conditions of accumulation of silver, gold and other impurities in copper sandstones and shale. Cand. Diss. Abstract]. Irkutsk, 1969. 23 p.

7. Bogdanov Yu.V., Buryanova E.Z., Kutyrev E.I. Stratifitsyrovannye mestorozhdenia medi SSSR [Stratified copper deposits of the USSR]. Leningrad, Nedra Publ., 1973. 312 p.

8. Volodin R.N., Chechetkin V.S., Trubachev A.I. Udokanskoe mednoe $i$ Katuginskoe redkometallnoe mestorozhdeniya Chitinskoy oblasti Rosii [Udokan copper and Katugin rare metal deposits of the Chita region of Russia]. Chita, Poisk Publ., 2004. 522 p.

9. Krendelev F.P., Bakun N.N., Volodin R.N. Medistye peschaniki Udokana [Copper sandstones of Udokan]. Moscow, Nauka Publ., 1983. $248 \mathrm{p}$. 
10. Narkelyun L.F., Bezrodnykh Yu.P., Trubachev A.I., Salikhov V.S. Medistye peschaniki i slantsy yuzhnoy chasti Sibirskoy platformy [Copper sandstones and shales of the southern part of the Siberian platform]. Moscow, Nedra Publ., 1977. $223 \mathrm{p}$.

11. Narkelyun L.F., Salikhov V.S., Trubachev A.I. Medistye peschaniki $i$ slantsy mira [Copper sandstones and shale of the world] Moscow, Nedra Publ., 1983. 414 p.

12. Popov V.M. Plastovye mestorozhdeniya tsvetnykh metallov i voprosy ikh genezisa [Stratum deposits of non-ferrous metals and questions of their genesis]. Problemy genezisa [Problems of the genesis of ores]. Moscow, Nauka Publ., 1964. pp. 350-368.

13. Narkelyun L.F. Geologiya i orudenenie Dzhezkazganskogo mestorozhdeniya [Geology and mineralization of the Dzhezkazgan deposit]. Moscow, Nauka Publ., 1962. 131 p.

14. Bogdanov Yu.V. Kontaktovy metamorfizm medistykh peschanikov v rayone Udokanskogo mestorozhdeniya [Contact metamorphism of copper sandstones in the Udokan deposit area]. Zapiski VMO, 1963, vol. 92, no. 5, pp. 535-546.

15. Narkelyun L.F., Trubachev A.I. Indikatory osadochnogo formirovaniya stratiformnykh mestorozhdeniy medi [Indicators of sedimentary formation of stratiform copper deposits]. Litogenez i rudoobrazovanie [Lithogenesis and ore formation]. Moscow, Nauka Publ., 1989. pp. 64-78.

16. Korolkov A.T., Radomskaya T.A., Yagudzhinsky R. Genesis of Polish copper deposits. Bulletin of Irkutsk State University. Series «Earth Sciences», 2016, vol. 17, pp. 91-102. In Rus.

17. Trubachev A.I., Korolkov A.T., Duchmal-Chernikiewicz A., Radomskaya T.A. Genetic models of formation of cupriferous sandstone and shale deposits (examples from Jezkazgan, Udokan and the Lubin - Gìogów Copper District). Petrological and mineralogical studies in geology: VIII Polish Conference. Abstrakts. Crakow, Poland, 1-2 June 2017. pp. 53.

18. Trubachev A.I. Formatsionno-parageneticheskiy analiz medistykh peschanikov i slantsev, zakonomernosti ikh razmesheniya $i$ genezis [Formation-paragenetic analysis of copper sandstones and shale, the regularity of their location and genesis]. Chita, ChitSU Publ., 2009. 347 p.

19. Trubachev A.I., Salikhov V.S., Vasilev V.G. Stratiformnye mestorozhdenia Zabaykalya [Stratiform deposits of Transbaikalia]. Chita, ZabGU Publ., 2014. 305 p.

20. Gablina I.F. Usloviya medenakopleniya $v$ krasnotsvetnykh kontinentalnykh formatsiyakh [Copper accumulation conditions in red continental formations]. Moscow, Nauka Publ., 1983. 111 p.

21. Domarev V.S. Osobennosti raznovozrastnykh mestorozhdeniy medistykh peschanikov [Peculiarities of uneven-age deposits of copper sandstones]. Problemy mineralogii i petrologii [Problems of mineralogy and petrology]. Leningrad, Nauka Publ., 1972. pp. $147-158$.

22. Belevtsev Ya.N. Metamorfogennoe rudoobrazovanie [Metamorphogenic ore formation]. Moscow, Nedra Publ., 1979. 275 p.

23. Ruchkin G.V. Model regionalnogo metamorfizma dokembriyskikh kolchedannykh mestorozhdeniy [Model of regional metamorphism of Precambrian pyrite deposits]. Geologiya rudnykh mestorozhdeniy, 1981, no. 5. pp. 19-32..

24. Garrels R.M., Christ Ch.L. Rastvory, mineral, ravnovesiya [Solutions, minerals, equilibria]. Moscow, Mir Publ., 1968. 368 p.

25. Marakushev A.A. Termodinamicheskaya osnova obrazovaniya paragenezisov khimicheskikh elementov v protsessakh glubinnogo mineraloobrazovaniya [Thermodynamic basis of formation of parageneses of chemical elements in deep mineral formation]. Ocherki fiziko-khimicheskoy petrologii [Sketches of physico-chemical petrology]. Moscow, Nauka Publ., 1975. Vol. 5, pp. 121-194.

26. Bezrodnykh Yu.P., Narkelyun L.F., Trubachev A.I. 0 strukturakh tipa raspada tverdogo rastvora v rudakh Udokanskogo mestorozhdeniya [0n the structures of solid solution decomposition type in the ores of the Udokan deposit]. Trudy Irkutskogo politekhnicheskogo instituta [Proc. of the Irkutsk Polytechnic Institute]. Irkutsk, IPI Publ., 1968. No. 42, pp. 135-144.

27. Salikhov V.S. Usloviya obrazovaniya i strukturno-veshchestvennye osobennosti stratiformnogo mednogo orudenenia [Formation conditions and structural and material features of stratiform copper mineralization]. Chita, ChitSU Publ., 2008. 377 p.

28. Satpaeva M.K. Rudy Dzhezkazgana i usloviya ikh formirovaniya [Dzhezkazgan ores and conditions of their formation]. Alma-Ata, Nauka Publ., 1985. 208 p.

29. Gablina I.F. Metamorfizm i gipergenez medistykh peschanikov $i$ slantsev. Avtoreferat Dis. Dokt. nauk [Metamorphism and hypergenesis of copper sandstones and shale. Dr. Diss. Abstract]. Moscow, $1994.45 \mathrm{p}$.

30. Pitulko V.M. Vtorichnye oreoly rasseyaniya $v$ kriolitozone [Secondary aureole of dispersion in the cryolithozone]. Leningrad, $\mathrm{Ne}$ dra Publ., 1977. 198 p.

31. Yurgenson G.A., Bezrodnykh Yu.P. 0 zone okisleniya Udokanskogo mestorozhdeniya medi i ee roli v formirovanii temperaturnogo polya mnogomerzlotnykh porod [On oxidation zone of the Udokan copper deposit and its role in formation of temperature field of permafrost]. Geokriologicheskie usloviya Zabaikalskogo Severa [Geocryological conditions of the Trans-Baikal North]. Moscow, Nauka Publ., 1966. pp. 53-55.

32. Yurgenson G.A., Gavrilov A.M., Ilmenev E.S. Mineraly kobalta mestorozhdeniya medi Aynak [Cobalt minerals of copper deposits in Ainak]. Zapiski VMO, 1985, vol. 4, pp. 428-434. In Rus.

33. Mendelson F. Medny poyas Severnoy Rodezii [Copper belt of Northern Rhodesia]. Moscow, IL Publ., 1963. 474 p.

34. Aman A., Solovev N.N. Stratiformnoe mestorozhdenie medi Aynak (Afganistan) i glavneyshie kriterii ego prognoza [Ainak stratiform copper deposit (Afghanistan) and the main criteria for its prediction]. Stratiformnye mestorozhdeniya [Stratiform deposits]. Chita, ChitPI Publ., 1982. pp. 100-109.

35. Annels A.E., Vaughan D.J., Craig J.R. Conditions of ore mineral formation in Zambian copper belt deposite with special reference to the role of cobalt. Mineralium deposita, 1983, vol. 18, no. 1, pp. 71-88.

36. Alderton D.H.M., Selby D., Kucha H., Blundell D.J. A multistage origin for Kupferschiefer mineralization. Ore Geol. Rev., 2016, vol. 79 , pp. 535-543.

37. Asael D., Matthews A., Bar-Matthews M., Harlavan Y., Segal I. Tracking redox controls and sourses of sedimentary mineralization using copper and lead isotopes. Chemical Geology, 2012, vol. 310-311, pp. 23-35.

38. Brown A.C. Close linkage of copper (and uranium) transport to diagenetic reddening of «upstream» basin sediments for sedimenthosted stratiform copper (and roll-type uranium) mineralization. Journal of Geochemical Exploration, 2006, vol. 89, no. 1-3, pp. $23-26$.

39. Boyle R.W., Brown A.C., Jefferson C.W., Jowett E.C., Kirkham R.V. Sediment-hosted stratiform copper deposits. Ottawa, Geological Association of Canada, 1989. Vol. 36, Special paper, 710 p.

40. Chmielewski A., Oszczepalski S., Speczik S. Relict mineralization in the transition zone, Kupferschiefer series of SW Poland. Mineral resources in a sustainable world. Ed. by A.S. Andre-Mayeriin. Nancy, Universite de Lorraine. Proceedings, 2015. Vol. 5, pp. 1897-1900.

41. Dziewińska L., Tarkowski R. Geophysical study of deep basement structure of NW Poland using effective reflection coefficients. C. R. Geosci., 2016, vol. 348, pp. 587-597.

42. Dziewińska L., Pepel A., Tarkowski R., Zuk Z. A new insight on the results of geophysical research of the Fore-Sudetic area in terms of prospecting for mineral deposits. Biuletyn Państwowego Instytutu Geologicznego, 2017, vol. 468, pp. 165-174. In Polish.

43. Ehrlich S., Butler I., Halicz L., Rickard D., Oldroyd A., Matthews A. Experimental study of the copper isotope fractiona- 
tion between aqueous $\mathrm{Cu}(\mathrm{II})$ and covellite, $\mathrm{CuS}$. Chemical Geology, 2004, vol. 209, no. 3-4, pp. 259-269.

44. Handbook of strata-bound and stratiform ore deposits. V. 6. Cu, $\mathrm{Zn}, \mathrm{Pb}$, and $\mathrm{Ag}$ Deposits. Ed. by K.H. Wolf. Amsterdam, Elsevier, $1976.573 \mathrm{p}$.

45. Harańzyk C. Petrography classification of the Zechstein copperbearing rocks from Silesia. Bull. Acad. Polon. Sci. Geol. Geogr., 1964, vol. 12, no. 12, pp. 19-25.

46. Harańczyk C., Jarosz J. Mineraly kruszcowe zloza miedzi monokliny Przedsudeckiei [Minerals crushing copper monocline Predsudetskoi]. Rudy i Metale niezelazne, 1973, vol. 18, no. 10, pp. 398-493.

47. Hitzman M.W., Selley D., Bull S. Formation of sedimentary rockhosted stratiform copper deposits through earth history. Economic Geology, 2010, vol. 105, no. 3, pp. 627-639.

48. Konstantynowich E. Mineralizacia utworow cechstynu nieki polnochsudeckiej [Mineralization compositions of Zechstein copper deposits, Northern Sudety]. Warczawa, Wydawnictwo Geologiczne, $1965.84 \mathrm{p}$

49. Kozub-Budzyń G.A., Piestrzyński A. Geochemical characteristic of Ag-bearing minerals occurring in copper ore deposit at the $\mathrm{F}_{0}$ re-Sudetic Monocline. Biuletyn Państwowego Instytutu Geologicznego, 2017, vol. 468, pp. 49-60. In Polish.

50. Król P., Sawlowicz Z. Massive copper sulphide mineralization in dolomites from the Lubin mine (Fore-Sudetic Monocline). Biuletyn Państwowego Instytutu Geologicznego, 2017, vol. 468, pp. 29-48. In Polish.

51. Kucha H. Pt-group in Cu-deposits Poland. Ecom. Geol., 1982, no. 6 , pp. $1578-1591$.

52. Kucha H. Precious metal bearing shale from Zechstein copper deposits, Lower Silesia Poland. Trans. Inst. Mining and Met., 1983, B. 92, pp. 72-79.

53. Kucha H., Bil B.W. The characteristics of ore mineralization in the Weisswasser copper district, Germany. Biuletyn Państwowego Instytutu Geologicznego, 2017, vol. 468, pp. 143-152. In Polish.

54. Mathur R., Ruiz J., Titley S., Liermann L., Buss H., Brantley S. $\mathrm{Cu}$ isotopic fractionation in the supergene environment with and without bacteria. Geochimica et Cosmochimica Acta, 2005, vol. 69 , no. 22 , pp. 5233-5246.

55. Mikulski S.Z., Stein H.J. Re-Os ages for Ag-bearing $\mathrm{Cu}$ sulphide ores from the Kupferschiefer in Poland. Proc. of the $13^{\text {th }}$ Biennial SGA Meeting. Nancy, France, 24-27 August 2015. Nancy, Université de Lorraine, 2015. pp. 607-610.

56. Oszczepalski S., Chmielewski A., Speczik S. Variability of ore mineralization in the North-West-trending extension of the LubinSieroszowice deposit. Biuletyn Państwowego Instytutu Geologicznego, 2017, vol. 468, pp. 109-142. In Polish.

57. Oszczepalski S., Speczik S., Ma£ecka K., Chmielewski A. Prospective copper resources in Poland. Mineral Resources Manage ment, 2016, vol. 32, no. 2, pp. 5-30.
58. Pakala M., Asael D., Butler I.B., Matthews A., Rickard D., Pakala $\mathrm{M}$. Experimental study of $\mathrm{Cu}$ isotope fractionation during the reaction of aqueous $\mathrm{Cu}$ (II) with $\mathrm{Fe}(\mathrm{II})$ sulphides at temperatures between 40 and $200{ }^{\circ} \mathrm{C}$. Chemical Geology, 2011, vol. 289, no. $1-2$, pp. 31-38.

59. Pieczonka J., Wiæclaw D., Piestrzyński A., Kotarba M.J., Rożłk R., Jedlecki R., Szarowski W., Wìndarczyk M. Relationship between the occurrence of ore minerals and geochemical properties of organic matter in the Kupferschiefer strata, KGHM Polska miedź S.A. mining area. Biuletyn Państwowego Instytutu Geologicznego, 2017, vol. 468, pp. 9-28. In Polish.

60. Piestrzyński A., Pieczonka J., Cwiertnia T., Zygo W. Geology of the European Kupferschiefer, Lubin, Poland. Geological Excursion Guide, $13^{\text {th }}$ Biennial SGA Meeting. Nancy, France, 24-27 August 2015. $51 \mathrm{p}$.

61. Radliński M., Sawìwicz Z. Altered rhythmic sulphide bands in the Weissliegens sandstone in the Rudna mine (Fore-Sudetic Monocline, Poland). Biuletyn Państwowego Instytutu Geologicznego, 2017, vol. 468, pp. 61-78. In Polish.

62. Sokalska A. Lithological variability of the Kupferschiefer in depressions of the Weissliegend relief in the area of the Rudna and Sieroszowice copper deposits. Biuletyn Państwowego Instytutu Geologicznego, 2017, vol. 468, pp. 199-208. In Polish.

63. Stein H.J. Dating and Tracing the History of Ore Formation. Treatise on Geochemistry. $2^{\text {nd }}$ ed. Ed. by H.D. Holland, K.K. Turekian. Oxford, Elsevier, 2014. Vol. 13, pp. 87-118.

64. Mikulski S.Z., Stein H.J. Re-Os isotopic age of the $\mathrm{Cu}-\mathrm{Ag}$ sulphide ore and its mineralogical and geochemical characteristic from the Lubin-Polkowice mining area (SW Poland). Biuletyn Państwowego Instytutu Geologicznego, 2017, vol. 468, pp. 79-96. In Polish.

65. Trubachev A.I., Korolkov A.T., Duchmal-Chernikiewicz A., Radomskaya T.A. Genetic models of formation of cupriferous sandstone and shale deposits (examples from Jezkazgan, Udokan and the Lubin - Glogów Copper District). Petrological and mineralogical studies in geology: VIII Polish Conference. Abstrakts. Crakow, Poland, 1-2 June 2017. pp. 53.

66. Vaughan D.J. Sulfide mineralogy and geochemistry: introduction and overview. Reviews in Mineralogy and Geochemistry, 2006, vol. 61, pp. 1-5.

67. Zhu X.K., Guo Y., Williams R.J.P. Mass fractionation processes of transition metal isotopes. Earth and Planetary Science Letters, 2002, vol. 200, no. 1-2, pp. 47-62.

68. Zieliński K., Speczik S. Deep copper and silver deposits - a chance for Polish metal mining industry. Biuletyn Państwowego Instytutu Geologicznego, 2017, vol. 468, pp. 153-164. In Polish.

69. Zweeney M.A., Binda P.L., Vaughan D.J. Genesis of the ores of the Zambian copper belt. Ore geok. reu., 1991, vol. 6, no. 1, pp. 51-76.

Received: 27 August 2019.

\section{Information about the authors}

Aleksey I. Trubachev, Dr. Sc., professor, Transbaikal State University.

Aleksey T. Korolkov, Dr. Sc., professor, Irkutsk State University.

Tatiana A. Radomskaya, Cand. Sc., Vinogradov Institute of Geochemistry SB RAS. 